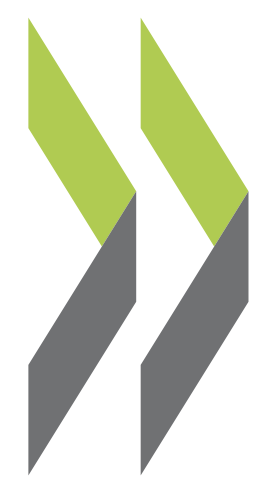

OECD Economics Department Working Papers No. 887

The Political Economy of Climate Change Mitigation Policies: How to Build a Constituency to Address Global Warming? 
Organisation de Coopération et de Développement Économiques

Organisation for Economic Co-operation and Development

05-Sep-2011

ECONOMICS DEPARTMENT

English - Or. English

THE POLITICAL ECONOMY OF CLIMATE CHANGE MITIGATION POLICIES: HOW TO BUILD A CONSTITUENCY TO ADDRESS GLOBAL WARMING?

ECONOMICS DEPARTMENT WORKING PAPERS No. 887

By Alain de Serres, John Llewellyn and Preston Llewellyn

All Economics Department Working Papers are available through OECD's internet web site at www.oecd.org/eco/workingpapers 


\section{ABSTRACT/RÉSUMÉ \\ The political economy of climate change mitigation policies: how to build a constituency to address global warming?}

Developments over the past few years have shown that reforms to address climate change are no less difficult to implement than reforms in other areas, even if the objective of limiting global warming is broadly accepted. In the case of global public goods such as the climate, the political challenge is further complicated by the need to convince voters that domestic action to reduce greenhouse gas emissions is worth taking, notwithstanding the cost and uncertainties regarding other countries' commitments. This paper seeks to draw a number of political-economy lessons from reform experience in other economic areas, and considers how these lessons can be applied to the particular case of climate change mitigation policy. It examines the main ingredients for building a constituency for greenhouse gas (GHG) emissions reduction policies at home, stressing the need to establish the credibility of the overall objective and intermediate targets. It also reviews the challenges faced in securing successful implementation of the least-cost set of policies, focusing on how to address the concerns raised by the uneven distribution of costs and benefits of pricing instruments without undermining their effectiveness.

JEL classification: Q52; Q54.

Key words: political economy; climate change mitigation; cost-effectiveness; carbon tax; competitiveness.

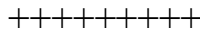

\section{L'économie politique de l'atténuation du changement climatique : comment assurer un soutien populaire en faveur d'actions pour enrayer le réchauffement planétaire}

Les discussions des dernières années ont montré que la mise en place de mesures pour atténuer le changement climatique peut s'avérer aussi difficile que la conduite de réformes économiques dans d'autres secteurs, même si l'objectif de limiter le réchauffement de la planète est largement accepté. Dans le cas d'un bien public comme le climat, le défi politique est accentué par la nécessité de convaincre les électeurs du bien fondé de l'action au plan national, malgré les coûts et les incertitudes concernant l'engagement des autres pays. Cette étude vise à tirer certains enseignements de l'expérience en matière de politique économique acquise lors de la mise en place de réformes majeures dans d'autres champs d'action, et à voir dans quelle mesure ces enseignements peuvent s'appliquer au cas particulier de la lutte au changement climatique. Les principaux ingrédients pour assurer un large soutien à des mesures efficaces de réduction des émissions de gaz à effet de serres sont passés en revue, de même que les défis que posent leur mise en place, ce qui nécessite de prendre en compte les inquiétudes concernant la distribution inégale des coûts et des bénéfices des instruments de prix en tout évitant de saper leur efficacité.

JEL classification : Q52; Q54.

Mots-clés : économie politique ; atténuation du changement climatique ; efficacité par rapport coût ; taxe carbone ; compétitivité.

\section{Copyright OECD 2011}

Application for permission to reproduce or translate all, or part of this material should be made to: Head of Publications Service, OECD, 2 rue André-Pascal, 75775 Paris CEDEX 16. 


\section{TABLE OF CONTENTS}

THE POLITICAL ECONOMY OF NATIONAL CLIMATE CHANGE MITIGATION POLICIES .......... 5

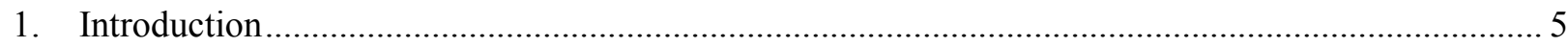

1.1 The challenge of addressing a distant threat in a difficult economic context ............................. 5

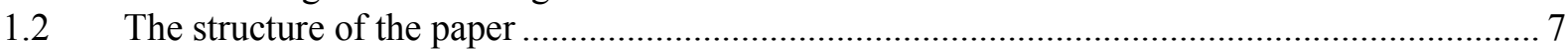

2. Building a broad and robust constituency for domestic climate change action:

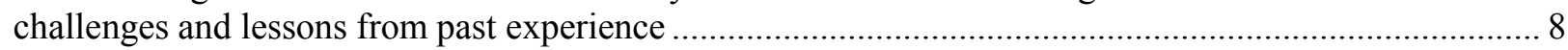

2.1 The objectives of climate change mitigation action have generally been well identified and

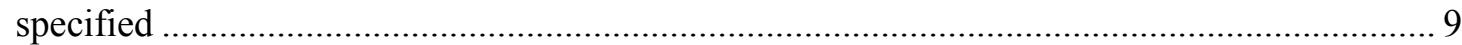

2.2 These objectives are still not seen as achievable and sustainable by a sufficiently broad share of the electorate..................................................................... 10

2.3 The main elements of a strategy to build a robust constituency to address global warming........... 13

2.3.3 Establish targets that are operationally feasible .................................................................. 15

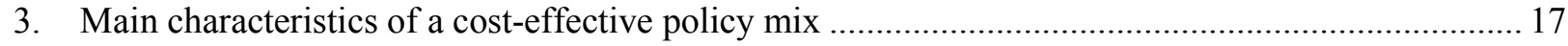

4. Political-economy challenges in implementing a cost-effective mitigation policy mix ...................20

4.1 Establish the cost of policy alternatives in a way that is directly comparable .......................... 21

4.2 The uneven distribution of costs and benefits of pricing instruments is raising concerns........ 22

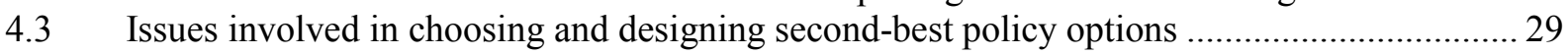

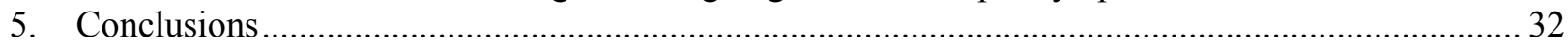

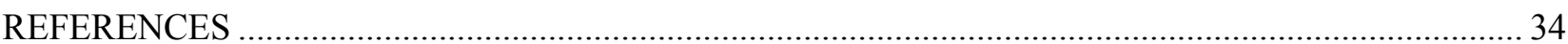

\section{Tables}

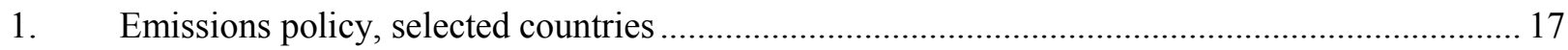

2. Subsidies to ethanol and biodiesel per ton of $\mathrm{CO}_{2}$ equivalent avoided in selected

OECD countries, lower bound estimates, 2006.

\section{Figures}

1. First-best, economically-optimal, lowest-cost, transitionpath (path I) ....................................... 19

2. Feasible, sub-optimal cost transition paths (paths II to IV from low to high cost) ...................... 19

\section{Boxes}

Box 1. General lessons of structural reform.

Box 2. Characteristics of low-cost policy design 
ECO/WKP(2011)56 
ECO/WKP(2011)56

\title{
THE POLITICAL ECONOMY OF NATIONAL CLIMATE CHANGE MITIGATION POLICIES
}

\author{
By Alain de Serres, John Llewellyn and Preston Llewellyn ${ }^{1}$
}

\section{Introduction}

\subsection{The challenge of addressing a distant threat in a difficult economic context}

1. Climate change is arguably the most difficult long-term global challenge facing the world economy. Although there is debate, even among the majority of scientists, about precisely what the figures should be, there is a basic consensus that, to keep risk at 'acceptable levels', the global average temperature increase needs to be limited to $2^{\circ} \mathrm{C}$ above pre-industrial times. This was reflected in the Copenhagen accord and later enshrined in the Cancun Agreement. To limit to 50\% the probability of an increase being greater than $2{ }^{\circ} \mathrm{C}$, global greenhouse gases (GHG) concentrations, it is estimated, need to be stabilised below $500 \mathrm{ppm} \mathrm{CO}_{2}$ equivalent $\left(\mathrm{CO}_{2} \mathrm{eq}\right)$ by 2050 , and below $450 \mathrm{ppm} \mathrm{CO}_{2}$ eq thereafter. All credible paths require global emissions to peak by around 2020 - at between 40 and $48 \mathrm{Gt}^{\mathrm{CO}_{2} \mathrm{eq}-\text { and to }}$ fall thereafter by at least $50 \%$ by 2050 (from 1990 levels) and by a further $50 \%$ by 2100 (from 2050 levels). ${ }^{2}$

2. As part of the Cancun agreement, around 80 countries - and all major emitters - have made pledges either to cut emissions (advanced countries) or to curb the rise in future emissions (developing countries) by 2020 . Even though they collectively fall short of what is viewed as necessary to meet the $2^{\circ} \mathrm{C}$ objective, the targets set by most OECD countries - though different - are perforce demanding. Slowing down, and then reversing, the growth of emissions of GHGs requires structural reform and major economic change. This offers potentially large opportunities; but also presents considerable political and economic challenges.

3. This paper seeks to draw political-economy lessons applicable to climate change policy from more general experience with structural reform around the world ${ }^{3}$, and considers how these lessons can be applied to the particular case of climate change mitigation policy. The relatively short history of reforms directly associated with the climate change mitigation objectives means, however, that any attempts to draw such lessons is to some extent speculative.

4. From an economic perspective, it has been shown that achieving ambitious mitigation objectives at a reasonable global cost is possible (OECD, 2009a). Doing so will require a sufficiently wide coalition of developing and developed countries agreeing on a set of policies and on a timeframe that is conducive to the gradual emergence of a broadly-based and uniform pricing of carbon. It has been suggested also that

1 The first author is Senior Economist in the OECD Economics Department; the second and third authors are Partners in Llewellyn Consulting. They would like to thank Niels-Axel Braathens, Crista Clapp, Anthony Cox, Romain Duval, Jorgen Elmeskov, Xavier Leflaive, Tony MacDonald, Helen Mountford, Giuseppe Nicoletti, Jean-Luc Schneider and William Tompson for helpful comments and suggestions, as well as Irene Sinha for editorial assistance.

2 This assumes lower global aerosol emissions which have a cooling effect (Bowen and Ranger, 2009). The 'climate responsible level' is judged to be $44 \mathrm{Gt} \mathrm{CO}_{2}$ eq. The current level of GHG is around $390 \mathrm{ppm}$ $\mathrm{CO}_{2} \mathrm{eq}$ and barring another major economic downturn, $450 \mathrm{ppm}$ is set to be reached by around 2030.

3 Including particularly labour market, product market, pension, and taxation reforms. 
such a uniform pricing of carbon (and other GHGs) at the international level might be best achieved through the implementation and eventual linking of national and regional tradeable permit systems. This is not because permit systems are intrinsically superior to taxes as a pricing instrument - if anything the latter are simpler to implement and do not require new institutions. However the built-in financial transfer mechanisms of cap-and-trade permit systems are seen as a key advantage in facilitating a separation between where the emission cuts take place and who pays for them. Alternative policies, such as subsidies for clean technologies and regulation, can play a useful role in a least-cost policy mix, but that role has to be complementary to carbon pricing, notably in targeting mitigation areas that fall out of the direct reach of market-based carbon policies.

5. In this regard, developments over the past two years have not been encouraging, with a number of major countries backing down from proposed legislation to introduce or extend the use of pricing instruments to address climate change. This suggests that what was perceived as being politically feasible not so long ago is turning out to be far more difficult to pursue, reflecting perhaps some erosion of popular support for climate change mitigation in general, and difficulty in rallying enough support for direct pricing measures in particular. ${ }^{4}$ Moreover, the financial hardship wrought on households by the recent economic crisis has not made gaining support any easier. The weak growth prospects in the coming years for many OECD economies stand only to add to this political difficulty, especially given that in the majority of OECD countries there is little scope for public spending to 'grease the wheel of reform'.

6. Another contributing factor is the lack of international coordination of action plans in individual countries, which makes it easier for the fossil-fuel industry and trade-exposed manufacturing sectors to invoke competitiveness and leakage concerns in lobbying against domestic action. Likewise, the implementation of carbon taxes that directly affect specific household activities can be more strongly resisted on the grounds that they are seen as potentially ineffective if implemented only locally.

7. A particular concern is that, faced with strong opposition to pricing measures, governments may seek to fulfil their Copenhagen commitments by relying essentially on policies, such as regulatory standards and subsidies (e.g. for the large-scale deployment of renewable energy technologies), which are politically more acceptable in the short term but generally not cost-effective in the medium term. Therefore, one question is to what extent fulfilling these commitments in such conditions can be achieved at an acceptable cost.

8. A related question is the extent to which the policy mix at the domestic level should be conditioned on the prospects of an internationally binding agreement being secured in the near term. For climate change, perhaps more than with other structural reforms, the international political economy dimension is crucial due to the global nature of $\mathrm{CO}_{2}$ emissions. Ultimately however policies have to be implemented at the national level, ${ }^{5}$ whether in the context of limited international agreements or, as is

$4 \quad$ Results from an opinion poll in the United States over a range of years showed that the share of the population that considered that global warming should be treated as a high or very high priority had fallen from 54\% in November 2008 to 44\% in June 2010 (Leiserowitz et al., 2010). However, the same poll showed that support for a tax on gasoline (combined with a cut in income tax) had changed little between 2008 and 2010 and remained low, at around 35\%. The generally weak support for pricing policies such as carbon taxes and cap-and-trade schemes in the United States was corroborated by another poll conducted on both sides of the US-Canada border (Borick, Lachapelle and Rabe, 2011). It showed that the support for such policy was substantially higher in Canada than in the United States (58\% vs 39\%) with the gap widening at higher assumed costs (58\% vs $18 \%$ if the cost was assumed to be $\$ 50$ per month), suggesting a higher willingness to pay in Canada. In both Australia and France, support for a carbon tax was found to decline significantly during the weeks after the government made concrete legislative proposals to implement such a tax.

5 Or regional level in the case of the European Union. 
perhaps more likely, in a less co-ordinated fashion. This paper focuses essentially on the national dimension. National opposition to mitigation policies arises for familiar reasons: the benefits are neither immediate nor entirely obvious, especially in the case of climate change, where domestic action has at best a limited impact on global emissions; policy imposes costs as well as benefits on society as a whole; and within society there are losers as well as winners.

9. For most countries the political economy of policy reform is central in determining the extent to which a society overcomes the challenge of reducing emissions and takes full advantage of its associated opportunities. Part of the challenge lies in choosing appropriate policies. But perhaps the greater part lies in implementing them, and this requires willing acceptance by all the principal actors - government, businesses, employees, consumers, and the public at large. For climate change policy this is at least as complex and difficult as in other areas of structural policy reform. In this regard, perhaps one advantage with reforms involving pollution emissions is the possible use of cap-and-trade systems to create early on a constituency in favour of reforms.

\subsection{The structure of the paper}

10. Section 1 examines the main ingredients for building a constituency for climate change mitigation policies at home, emphasising the importance that the objective be defined in terms that can be seen as both achievable and sustainable. Building a constituency for climate action is a necessary, but not sufficient, condition for the successful implementation of a policy package to achieve low-cost mitigation. Even when the case for mitigation appears to be broadly understood and supported by the population, policymakers remain confronted with a 'trade off' between economic efficiency and political feasibility. 'First-best' policy, while optimal, may nevertheless not be politically feasible: a 'second-best policy may be the only politically-feasible option. When there are a number of 'second-best' options, the task becomes one of choosing the lowest-cost of those options.

11. After reviewing the key characteristics of a successful low-cost policy action plan in Section 2, Section 3 identifies the main challenges associated with securing successful implementation of the chosen, politically feasible, minimum-cost set of policies. This includes, particularly importantly, how best to overcome resistance without going too far in granting exemptions, and how best to compensate those who lose out during the transition to a low-carbon economy. Major issues in this area include concerns of competitiveness and distribution.

12. The paper draws on various sources, including OECD (2009a,b) and OECD (2006). Several of the political economy issues raised by climate change mitigation policies are similar to those arising in the context of reforms in other areas. Some of the findings from the examination of earlier reforms are summarised in Box 1.

\section{Box 1. General lessons of structural reform}

Earlier analysis of a number of case studies covering both successful and failed attempts to introduce major reforms in OECD countries has led to a number of general lessons which can be expected also to apply in the context of climate change mitigation policies (OECD, 2009b):

- Strong leadership. Policy must be led by a well-trained, respected, committed, and cohesive team which includes technocrats and 'technopols', , who are both willing and able to lead and institute reform. When an electorate is being asked to make sacrifices for a brighter future, trust is important. Creating a constituency for reform frequently starts within government - often at cabinet level. If this is not achieved, including within the opposing political parties, disunity can lead to incoherence of the measures proposed: compromises adopted to appease various stakeholders complicate reform. In this context, the importance of 
having an electoral mandate for reform has emerged as one of the strongest findings from the analysis of earlier reforms.

- $\quad$ Strong Institutions. The ability, credibility, cohesion, and firmness of purpose of the political structure need to be emulated throughout the country's institutions (legislative, operational, and informational). Treasuries and finance ministries in particular play pivotal roles. They need to be able to override objections from other departments concerned with placating their constituencies. Political systems and institutions which allow the fostering of opposing powers to go unchallenged, and that cannot effect change quickly enough, often damage reform processes.

- Good economics is not necessarily bad politics. OECD case studies ${ }^{2}$ cast doubt on the oft-repeated claim that voters tend to punish reforming governments. While the number of cases involved is too small to permit generalisation, and while there have been important exceptions, many of the governments that successfully adopted and implemented reforms for which they had prior electoral mandates subsequently went on to win re-election.

- Employ change agents at all levels. The communication process can be aided by having change agents at all levels - sometimes called 'points of light' - people across society, ranging from business people to journalists to NGOs, who complement the top-down approach with more diverse, and more local, elaboration and support.

- $\quad$ More haste can lead to less speed. While governments need to be prepared to exploit political windows of opportunity for reform, those that are embarked on hastily can prove difficult to sustain once the extraordinary circumstances pass. Making use of political diversions to mask or hide controversial reform is also less effective for a long term gradualist reform. Successful reforms often have relatively long gestation periods, involving considerable study and consultation.

- Creating 'early winners' can help to change expectations and build interests in pressing for completion, thereby generating momentum for reform. That said, 'low-hanging-fruit' strategies can also pose problems of their own. Actions that start with certain sectors, and are seen as a harbinger of deeper reforms, may lead opponents to adopt an intransigent position in opposition to stall the process, even over relatively minor measures.

- In many cases, sequencing will be a luxury that political feasibility cannot afford. OECD and IMF econometric evidence supports the view that the most promising time for reform is immediately after a recession or election. In reality however there is never a truly good time to implement reform, and economies often have to live with the consequences that emerge from sub-optimal policy sequencing.

1. Economists in key policymaking positions, who may have a better picture of the available options and their economic and social consequences than career politicians. Technopols stand also to have a different motivation.

2. Twenty reform episodes in 10 OECD countries, over the period 1992 to 2008.

\section{Building a broad and robust constituency for domestic climate change action: challenges and lessons from past experience}

13. In most policy areas, building a constituency for reform involves establishing the credibility of the policy objective, and reinforcing that credibility over time. Indeed, experience from policy reforms across a range of countries suggests that, for democracies, it is of crucial importance that the objective be accepted as credible by the population in general, and often by investors in particular. Although credibility does not guarantee success, its absence significantly increases the chance of policy delay, or even failure. Credible policies are characterised by objectives that are perceived as clearly identified and specified, as well as achievable and sustainable (both technically and politically). In the case of global public goods, and certainly climate change, this political challenge is further complicated insofar as voters need to be 
convinced that domestic action to reduce greenhouse gas emissions is worth taking, notwithstanding the cost and uncertainties regarding other countries' commitments.

\subsection{The objectives of climate change mitigation action have generally been well identified and specified}

14. A first and important step towards establishing credibility and building a broad constituency for action is to communicate the dangers associated with inaction, using terms that are understandable to the wider public. As regards climate change, the case for mitigation action at the global level has been made and reinforced over time, first through the process leading to the Kyoto protocol in the mid-1990s and, more recently, through the international discussions and negotiations to establish its successor. The potential costs of the physical damage arising from rising sea levels, more frequent floods and droughts, and the associated degradation of ecosystems in particular, have been demonstrated and communicated through various channels. Increasing efforts are being made to provide impact assessments at the local level to enable the consequences to be illustrated in more concrete and targeted terms to which populations can more readily relate. Progress has also been made in valuing the physical damage in monetary terms, to enable comparison with the costs of mitigation policies.

15. The success and effectiveness with which such information has been communicated to the wider public differs across countries. Where governments have actively engaged in public awareness campaigns, indications are that the dissemination of the work (e.g. of the IPCC and other influential studies such as the Stern Report) has been successful in building broad - albeit fragile - support for mitigation action. For example, during the run-up to the 2007 presidential election in France, all major candidates inserted in their programmes the introduction of a carbon tax. In Australia, the strong commitment of the then opposition party in favour of carbon pricing is reckoned to have been a key factor behind its landslide victory in the 2007 election. In both cases, however, the follow-up to these commitments has been seriously compromised (see below).

16. Furthermore, the global emission pathways outlined by climate scientists have helped to identify and specify explicit policy goals. Notwithstanding the many and large uncertainties, there is at least a fairly broad consensus on how much more GHG the world can afford to emit if the rise in global temperature is to be limited to a specific range. This allows for explicit targets to be set, at least at the global level. Indeed, governments of both developed and developing countries have collectively adhered to the objective of keeping average temperature increases to no more than $2^{\circ} \mathrm{C}$, implying that the concentration of GHG be stabilised at no more than $450 \mathrm{ppm} \mathrm{CO}_{2}$ eq. In this respect, policy for climate change mitigation has arguably proved more straightforward than other environmental areas, such as bio-diversity.

17. One outcome of the Cancun meeting (COP16) is that governments of most OECD countries have now accepted not only the broad objective of reducing the risks that stand to arise from anthropogenic global warming, but also the shared responsibility to slow down, and then reverse, the growth of emissions of carbon dioxide and other GHGs. Acceptance of this responsibility - based primarily on historical emissions $^{6}-$ has been translated into national emission reduction targets. As a result, policy objectives for climate change mitigation are clearer and more tightly specified than many other economic policy objectives. The fact that the sum of the stated emission reduction targets at the national level falls short of the global objective set by world leaders ${ }^{7}$ need not necessarily undermine the credibility of the domestic

6 Industrialised nations are widely attributed as being responsible for the bulk of the anthropogenic GHG emissions to date. Over the coming decades (2010-30), however, the IEA reference scenario projects that global primary energy demand will increase substantially - by more than $40 \%$ - with more than $90 \%$ of this increase coming from non-OECD countries (IEA, 2009).

$7 \quad$ See Dellink, Briner and Clapp (2010) for an analysis. 
objectives, but is nevertheless unfortunate, as it risks perpetuating confusion while raising questions as regards the strength of commitments.

\subsection{These objectives are still not seen as achievable and sustainable by a sufficiently broad share of the electorate}

18. The clarity of the objectives notwithstanding, too many people remain unconvinced that they are achievable or sustainable, at least at an affordable cost. In this regard, opponents can be divided broadly into two categories according to the nature of their arguments or beliefs. A first category includes those who are fundamentally sceptical and will therefore always be difficult to convince.

- $\quad$ Not all people accept even the basic case for reducing GHG emissions. Few direct environmental or economic effects have yet been felt in OECD countries, and the expected damage is perceived by many as likely to be relatively low. If risks are undervalued, many people will be disinclined to respond.

- Others believe that it is too late to reverse the damage. Such positions base themselves on the belief that, even if the science is correct, the climate has gone beyond the 'tipping point'. On this argument, even if cuts are severe, they would make little discernable difference.

19. Another group of opponents understands the risks involved, but remains unconvinced either that it is worth bearing the cost of action, or that the threat is sufficiently imminent to warrant immediate action. This is a constituency that needs to be persuaded.

- Many are led to believe that emission reduction is incompatible with economic growth, and even risks producing an absolute fall in material living standards. Based on projected growth in population and economic catching-up in developing countries, many believe that meeting ambitious emission reduction targets would necessitate a degree of decoupling from material production at the global level that is not feasible under current technology. ${ }^{8}$ Achieving these objectives would therefore require a drastic shift in consumption and production patterns from material goods towards services, where productivity gains tend to be much lower (Jackson, 2010). To many, this is a good reason to push for such transformation. For many others, however, this is taken as an argument against climate change action.

- Emissions reduction will have a net cost, which many consider to be 'too great'. Even though in principle climate change mitigation could help raise revenues that could then be transferred to others by way of tax reductions, there will nevertheless be a net resource cost to the economy as a whole. Significant human and physical capital resources will need to be allocated to reducing emissions, some of which stands to be in new technologies which may not manage to get off the ground. These resources will thereby not be available for the consumption of other goods and services ${ }^{9}$. There is a range of estimates ${ }^{10}$ of the investment likely to be needed to combat climate change. These vary by region and the assumptions made. An emerging consensus seems however

$8 \quad$ Recent OECD model-based analysis has shown that emission cuts consistent with stabilising GHG concentration at $550 \mathrm{ppm} \mathrm{CO}_{2}$ eq can be achieved under existing technology (i.e. without CCS) and still allow for sustained increases - albeit at a slower pace - in living standards in both developed and developing countries (OECD, 2009a).

Such calculations take into account neither the potentially large benefits of mitigation through reduced damage from climate change nor the efficiency gains arising from better management of natural resources. 
to be that, for a $50 \%$ chance of limiting Earth's average temperature rise to $2{ }^{\circ} \mathrm{C}$ above preindustrial levels, and to provide adequate adaptation, annual expenditure of the order of $1-2 \%$ of global GDP will be required. However, this is not a particularly solidly-based figure, and considerably more work will need to be done before an estimate can be produced that will be sound enough to carry broad conviction.

- Many believe that the emission reduction targets are unrealistic. People do not see how the tough emission reduction targets, 'imposed' by governments, can be achieved and sustained over the relatively short time periods required. Although most countries have specified the broad objectives of national policy, fewer policies specify as clearly - i.e. at operational level - exactly how the targets are to be achieved, including in particular how the national and global reductions will be funded. Furthermore, there are concerns about the distributional implications of the policies needed to achieve the targets, as well as about their impact on the competitiveness of domestic firms (more on this in Section 4).

- Many also believe reductions risk not being achieved due to a lack of political will. Even many of those who accept the case for reducing emissions believe that lack of political will has prevailed, and will continue to do so. Even though an agreement was reached at Cancun, it does not include an explicit global emissions goal and few of the governmental emission reduction pledges are legally binding. Although these factors do not, in themselves, mean that nations are not committed to emission reductions, or that the pledges will not be met, the consequent lack of coordination of action plans in individual countries adds to uncertainty. In this regard, it is possible that the outcome of the Copenhagen summit (COP15), in combination with slow progress under the United Nations Framework Convention on Climate Change (UNFCCC) and on national policy developments, may have had a net negative impact on business incentives to invest in mitigation insofar as the policy signal and commitment have been blurred. And whether the progress made at Cancun will be interpreted as a stronger, clearer signal by businesses remains to be seen.

- $\quad$ Other critics argue that it does not pay to be first. That first-mover advantages are not perceived as obvious can be exploited successfully by those opposing policy, as was recently demonstrated by opponents to the emission trading system in Australia. The central theme rested on the argument that the country had little to gain (and potentially much to lose) by going ahead before others do the same. One reason might be the fear that others will not follow suit. Another argument, linked to the strategy of international negotiations, is that being first may imply having to adopt higher emission objectives in a future agreement.

- As with other structural reforms, the cost tends to be borne 'up front'. The likely benefits, which are neither immediate nor unequivocal, stand to be realised in the future. In the case of climate change mitigation policy, the future can be particularly distant, and benefits are spread across countries. Sometimes economic theory is all that is available but it can, nevertheless, be sufficient to gather enough support for reform. ${ }^{11}$

20. Overall, it is a fundamental challenge for policymakers to convince the public that they should endure a certain cost today in exchange for an uncertain benefit that will be spread across the world tomorrow. The willingness to accept this class of argument, one that has strong inter-generational and public-good dimensions, differs widely across countries, including across those in the OECD. Furthermore,

11 For example, free trade has been 'sold' fairly consistently, over the past fifty years, largely on the basis of theory (of comparative advantage), notwithstanding the fact that, like climate change, the move imposes costs that are immediate and fairly clear, whereas the benefits tend to come later and are more diffuse. 
meeting anything like the broadly-accepted emissions target would require, in a world of growing population and GDP, basic changes in what is produced, and how it is produced, implying in turn that consumer and business behaviour needs to change fundamentally, and relatively quickly. Deep change can be particularly unsettling even to those who may not feel directly threatened by the impact of action.

21. Furthermore, a number of factors have led to the reduction in support for mitigation over the past two years.

- The economic crisis dented the enthusiasm of many, and pushed environmental concerns several steps down the list of major concerns. The sharp and persistent rise in unemployment in many countries, and the increased economic uncertainty, has had an impact on voters' willingness to bear any direct additional cost to tackle climate change mitigation.

- Although the case for mitigation action initially benefited from increased media attention during the run-up to Copenhagen, support waned upon realisation that a binding agreement would not emerge. The fact that the emergence of a binding agreement came to be seen in the media as what would define success at COP15 may have contributed to the build-up of unrealistic expectations. Again, the progress achieved in Cancun, at least measured against better-managed expectations, may help restore credibility in the process and support for mitigation action.

- The erosion of support may have been further exacerbated by the poor or misrepresented practices in a number of research organisations, which have damaged the credibility of the science as a whole, amid confusion and uncertainty. None of this has changed the nature of the evidence, which remains overwhelmingly in support of the link between man-made activities, GHG emissions, and global warming. Nevertheless, an impression has been left in the minds of many that the evidence may not be as solid as previously accepted; and one direct consequence has been to give more weight to the arguments of those who resist action to cut emissions. ${ }^{12}$

22. The change observed over the past two years has shown that credibility and support for mitigation action can easily be lost, and that vigorous efforts stand to be required to rebuild a sufficiently broad constituency for a successful policy. More effective communication and pedagogy may be necessary. One reason is that no matter how solid the scientific, and even the economic, case for mitigation action, there will always be powerful forces that want to keep the status quo, and will do whatever they can to undermine the case. The challenge for governments therefore goes beyond informing the public. It must also prevail in a communication battle against powerful lobbies prepared to invest considerable resources to influence politicians, both directly through the funding of election campaigns, and indirectly by arguing against action, often on the grounds of legitimate concerns. Furthermore, in many sectors, such as energy, the power of incumbents is such that they can better take advantage of asymmetrical information over policymakers and regulators to influence decisions, notably by selling their interest as "national interests" (Helm, 2010).

12 The results from the poll mentioned earlier pointed to an increase (from $38 \%$ in 2008 to $47 \%$ in 2010 ) in the proportion of Americans who feel that the scientists are overstating the evidence against global warming (Borick, Lachapelle and Rabe, 2011). Likewise, the proportion of Americans who consider that there is solid evidence of global warming fell from $72 \%$ to $52 \%$ in the spring of 2010 , before climbing again to $58 \%$ in the fall of 2010 . The fact that the summer of 2010 was the fourth warmest on record in the United States (and the warmest ever in some Eastern States) may have contributed to the rebound. 
ECO/WKP(2011)56

\subsection{The main elements of a strategy to build a robust constituency to address global warming}

23. Establishing, and then building upon, a constituency for climate change reform requires that many of the aforementioned arguments be addressed in order for the most economically-feasible policy to be accepted by a sufficient share of the electorate, as necessary, achievable and desirable.

\subsubsection{Establish the credibility of the science to prove that action is necessary}

24. Policymakers might consider going right back to the beginning and build the scientific case for mitigation. Ultimately, the whole of policy rests on this cornerstone. Experience has shown that in many policy areas the case for reform often needs to be reframed and hammered out several times, even if this involves repeating what is thought to be well known. For instance, this has been the experience with pensions, where calls for reforms to cope with future demographic change were made already in the 1980s, well before significant reforms were undertaken. ${ }^{13}$ Previous policy experience also suggests that this should involve:

- Clearly and simply spelling out the consequences and risks of inaction by setting out the 'cold' facts that stand to result from "business as usual" (BAU) emission levels. The consequences should be framed in ways that people can understand and with which they can identify.

- For the OECD countries, putting particular emphasis on the indirect effects of climate change. For example, policies of 'planned retreat' for vulnerable coastal locations, aimed at pushing future developments back from the coast, have been in place for years in many countries. One Australian local authority's objective ${ }^{14}$ as part of this policy is to cease undertaking beach protection measures on certain vulnerable but costly stretches. Although recently overturned by a court ruling, it is indicative that many existing, and expensive, properties around the world that are at risk from climate-change stand progressively to become uninsurable.

- Solid and credible data - visibly 'neutral', and distant from politics. The recent announcement of a reform of management structure of the International Panel on Climate Change (IPCC) to bolster its independence and transparency can be seen as an example of a move in that direction. ${ }^{15}$

- Perhaps more effort should be made to avoid presenting scientific evidence in a way that sounds definitive. No good scientist would, and no politician should, ever present scientific understanding as completely certain: to do so is bad scientific method. Science knows no certainties, only probabilities. However, communicating a scientific range of probabilities to the wider public can be challenging, as those involved in the forecasting business know well.

25. It would be more compelling, as well as better science, to seek to establish credibility by argumentation along the following lines:

\footnotetext{
13 Indeed a number of parallels can be drawn between pensions and climate change. In both cases, the costs and benefits stand to be unevenly distributed across generations, and delaying reform generally raises the (economic) cost. One major difference, however, is that pensions are essentially a domestic issue.

Byron Shire Council, NSW, Australia in February 2010: (source: theaustralian.com)

15 The changes follow the recommendations made by the Inter-academy Council, a coalition of national science organisations mandated by the United Nations to review the structure and procedures of the IPPC to identify areas of weaknesses.
} 
- Man-made emissions of greenhouse gases are leading, in the judgement of the majority of scientists, to a warming of Earth.

- Unless checked and then reversed, this risks provoking potentially major changes in Earth's climate. Such changes in turn risk being expensive in economic, social, and political terms; and could be catastrophic.

- As Earth continues to warm, water, food, and disease management will become increasingly important, regionally and globally. Asia, southern Europe, the Americas, Africa and the Middle East are all set to experience greater inland and coastal flooding, drought, and extreme weather conditions.

- BAU projections by the OECD and others put GHG concentration by 2050 at $580-650$ ppm $\mathrm{CO}_{2}$ eq and by 2100 at $800-900 \mathrm{ppm} \mathrm{CO}_{2}$ eq. At such levels, swathes of the world, including a considerable part of Asia, stand to be devastated, variously by desertification, rising sea levels, and extreme weather conditions. Forced mass migrations would further intensify conflict over resources.

- None of this is certain, but most decisions in life have to be taken in the face of uncertainty. In fact, the high degree of uncertainty could be cast more forcefully as a good reason to act. Perhaps estimates of mitigation costs could be presented as a form of a (small) insurance premium against the risk of potential significant damage. Conversely, preliminary estimates from the work on climate change adaptation could be used to illustrate that a wait-and-see approach could lead to much higher premia to insure against eventual climate damage related risks.

- Rising GHG concentrations raise earth's temperature only with a long lag. Waiting until the science is virtually certain before acting - as many sceptics advocate - would likely ensure it was too late to avoid climate catastrophe. Delay would seem likely only to increase risk further. And the risks are already too great to make inaction the sensible course.

26. Some will not be convinced, whatever the argument and the evidence, but many will.

2.3.2 Make clear the case that addressing climate change is compatible with rising living standards and, in particular, improving wellbeing

27. With the impact of climate change still seen by many as distant, many voters tend to be sensitive to the costs of action. It is therefore important to dispel myths about the potential costs of mitigating climate change including, in particular, the notion that it is incompatible with strong economic growth, let alone that it may result in an absolute drop in living standards.

28. Uncertainties about the costs of mitigation action are large, though perhaps less so than for benefits. Nonetheless, different model-based analyses suggest that moderately ambitious emission reduction targets can be achieved at an economic cost that the advanced economies at least can certainly afford. For example, using a model specifically suited to examine climate change mitigation scenarios, OECD analysis has suggested that stabilising the concentration of GHG's to $550 \mathrm{ppm} \mathrm{CO}_{2}$ eq could be 
achieved at low global cost, even in the absence of technological breakthrough. ${ }^{16}$ Evidently, this corresponds to a first-best scenario that depends on a number of conditions unlikely to be met in practice, if only because it ignores potential government failures. And precisely for that reason, the cost of action should not be downplayed either, as this could undermine the credibility of the broader message.

29. The point is that in communicating the costs of mitigation, it is important to make clear that foregone output growth is not the same as an absolute reduction in GDP. Even a significantly more costly cumulative outcome than suggested by the first-best course of action would still leave populations around the world vastly richer in 2050 than they are today. In fact, mitigation is not incompatible with continuously rising living standards, provided that action is sustained and taken sufficiently early to enable the pool of low-cost abatement options to be tapped first. ${ }^{17}$ While this will not persuade those who stand to lose most from climate change policies, it may at least help to build support for mitigation among the broader population. At a deeper level, it may also be useful to stress the limitations of focusing too narrowly on GDP as a measure of well-being. Ultimately, it is the latter that matters and gains in wellbeing from mitigating climate change can be substantial, including through improved health conditions. This may be helpful in avoiding inaccurate interpretations of trade-offs between economic growth and addressing climate change.

\subsubsection{Establish targets that are operationally feasible}

30. To increase the political feasibility of national policy, policymakers must ensure that policy targets are achievable, and be able to demonstrate operational feasibility. Policy objectives that are credible technically, and are demonstrated as such, are more likely to withstand political opposition. Given the current trend in total emissions, and the national commitments made for 2020, it is clear that in order to be achieved, the internationally-set objective of stabilising emissions below $450 \mathrm{ppm} \mathrm{CO}_{2}$ eq will require far more drastic global emission reductions in the period beyond 2020. In the case of an inter-temporal problem such as climate change, it is politically natural - and therefore not unusual - for governments to backload the efforts (and costs) by setting targets that are far more demanding in the long term than in the short term.

31. What is fundamental, however, is that the policy strategy underpinning the short-term commitments be adequately demonstrated as operationally achievable. This is all the more important given that failure by many countries to meet their Kyoto commitments means that they will start with a credibility gap. Evidence from previous policy reforms suggests that policy that is not perfect, but which is politically feasible, is usually better than no policy at all: it may make sense to "take what you can get". Total failure is rare, while setbacks and less successful attempts often help set the stage for subsequent, sometimes more far reaching, initiatives. This suggests that if the existing policy can be demonstrated to be 'nearly there', there stands to be enough credibility for implementation; and that, as time passes, policy might be able to be strengthened to make up the difference.

\footnotetext{
16 That is, without relying on carbon capture and storage (CCS) or other technologies that remain unproven on a large scale. The simulation results suggest that stabilisation of GHG concentrations at $550 \mathrm{ppm}$ according to a path of emissions that would peak in 2025 would lead to a reduction of world GDP growth of 0.11 percentage points per annum on average, resulting in world GDP being lower by about $4 \%$ in 2050 relative to a business-as-usual baseline scenario (OECD, 2009a). 


\subsubsection{Adopt institutions which better mobilise potential winners}

32. Institutions and special interest groups can also increase political voice and contribute usefully, such as with negotiation, and thereby help to de-politicise sensitive reform issues. 'Permanent' independent and impartial institutions or public bodies often carry more weight than ad hoc special committees and commissions (Ekins and Salmon, 2010). Not only can they help in establishing the credibility of policy reforms, but they can also help to foster consensus on basic issues, including the costs and benefits of both the status quo and reform. Responsibility for decisions can also be delegated to the apolitical bodies.

\subsubsection{Invoking other externalities and co-benefits can only go so far}

33. In principle, where the consequences of climate change alone fail to persuade, other potential benefits from mitigation action - which may also appear more tangible to voters - can be used positively. Indeed, both the US and the EU authorities have invoked energy security as reason to push for 'homegrown' domestic energy sources so as to minimise the risk of disruptions in energy supply, either through interruptions in physical deliveries or price instability. ${ }^{18}$ In the case of the oil market, the recent trend of rising and highly volatile prices is likely to persist in the foreseeable, at least under normal global economic conditions (CAE, 2010). And, while supplies from conventional reserves remain for the most part exposed to geo-political uncertainties, more secure sources from non-conventional reserves, such as those from tar sands or offshore drilling, are subject to far higher extraction costs and adverse environmental side-effects. However, the abundance of non-conventional (shale) gas reserves in North America and parts of Europe and China may have diminished the strength of the security argument, even though climate change policy could facilitate the switch from carbon-intensive oil and coal towards less carbon-intensive gas. Furthermore, such argument carries less weight in large coal-producing countries where the gains in energy security tend to be lower.

34. Another potential co-benefit from climate change mitigation is the decline in premature deaths related to lower incidence of local air pollution. However, while such co-benefits are found to be large not least in OECD countries where transport is the major source of local air pollution (Bollen et al., 2008) - they are unlikely to constitute a strong argument in favour of climate change action. One reason is that similar reductions in local air pollution can be achieved at relatively low cost through direct policies, rather than through costlier indirect mitigation action.

\subsubsection{Establish the case that the political will is set to prevail}

35. The outcomes of the Copenhagen (COP15) and Cancun (COP16) summits were not, by themselves, enough to put the world on a path to limit Earth's warming to $2^{\circ} \mathrm{C}$. But neither were they a 'failure' or a 'make or break' event. In many ways, Cancun consolidated the outcomes of Copenhagen, in that several significant steps were taken towards the implementation of its key elements. But it also made progress in areas not directly covered in Copenhagen. It may be useful to briefly stress the commitments that were made.

- Most countries - including all the major economies - agreed to provide targets and actions to reduce emission by 2020 (Table 1);

18 For example, lifting the 20-year moratorium on offshore drilling was key to winning support of the US Senate for the American Clean Energy and Security Act Energy bill (ACES) even though this was ultimately insufficient. In the meantime, the oil spill off the Gulf of Mexico in April 2010 has made such expansions of offshore drilling politically more difficult. And, the ambitious EU $20 \%$ target for the share of renewable in electricity generation by 2020 is motivated at least as much by energy security considerations as environmental ones. 
- Advanced economies have pledged significant funding for mitigation and adaptation, including through the establishment of a Green Climate Fund;

- A structure is being put in place to facilitate the diffusion of technologies for clean energy and adaptation to climate change;

- Steps are being taken to protect tropical forests, notably through the establishment of a programme allowing advanced countries to help prevent deforestation in developing countries;

- Further progress was made in strengthening the mechanisms for monitoring and verification that was laid out in the Copenhagen accord.

36. In the meantime, the pledge of USD 30bn at COP15 - earmarked primarily to aid adaptation in vulnerable countries over the coming three years - is being implemented, and much effort is being put into determining how the longer term financial promises - of jointly mobilising USD $100 \mathrm{bn}$ a year by $2020-$ are to be put into effect.

\section{Main characteristics of a cost-effective policy mix}

37. Once a constituency for action has been established, the challenge is to analyse options with a view to establishing the costs of alternative policy mixes that have the potential to achieve the mitigation objectives. The range of actions to secure a politically feasible least-cost outcome, including identifying potential losers, is the focus of the next section. This section briefly summarises the main characteristics of a cost-effective policy mix to achieve ambitious emission reductions targets at the national level.

38. Putting a price on the emission of greenhouse gases - through either taxes or emission rights - is generally the most cost-effective way to address climate change (Box 2). However, it is also recognised that where pricing emissions fails to work due to information gaps or other market failures, alternative policy measures such as subsidies for clean alternatives (e.g. renewable energy), or the use of regulation such as the imposition of performance or technology standards, can be more effective (see e.g. Duval, 2008). Furthermore, new technologies are needed to lower future abatement costs, but the development of untested technologies is generally hampered by path-dependency effects that can be overcome only with well-designed innovation policies. The best policy strategy will therefore involve a combination of complementary instruments, the precise mix of which will differ across countries according to the nature and size of the predominant market failures and the differences in institutional capacities.

Table 1: Emissions policy, selected countries

\begin{tabular}{|c|c|c|}
\hline & $\begin{array}{l}\text { Applicable } \\
\text { to }\end{array}$ & $\begin{array}{l}\text { Reduction target } \\
\text { (by 2020) }\end{array}$ \\
\hline \multicolumn{3}{|c|}{ Reduction in emission levels relative to a specified year } \\
\hline EU & $\begin{array}{l}\text { Kyoto } \\
\text { GHGs }\end{array}$ & $20 \%$ from 1990 levels \\
\hline United States & $\begin{array}{l}\text { Kyoto } \\
\text { GHGs }\end{array}$ & $17 \%$ from 2005 levels \\
\hline Japan & $\begin{array}{l}\text { Kyoto } \\
\text { GHGs }\end{array}$ & $25 \%$ from 1990 levels \\
\hline
\end{tabular}




\begin{tabular}{|c|c|c|}
\hline Australia & $\begin{array}{l}\text { Kyoto } \\
\text { GHGs }\end{array}$ & $5-25 \%$ from 2000 levels \\
\hline New Zealand & $\begin{array}{l}\text { Kyoto } \\
\text { GHGs }\end{array}$ & $10-20 \%$ from 1990 levels \\
\hline South Korea & $\begin{array}{l}\text { Kyoto } \\
\text { GHGs }\end{array}$ & $4 \%$ from 2005 levels \\
\hline \multicolumn{3}{|c|}{ Reduction in emission intensity or relative to a business-as-usual scenario } \\
\hline China & $\begin{array}{l}\text { Carbon } \\
\text { Intensity }\end{array}$ & $\begin{array}{l}40-45 \% \text { per unit of GDP, } \\
\text { from } 2005 \text { levels }\end{array}$ \\
\hline India & $\begin{array}{l}\text { Carbon } \\
\text { Intensity }\end{array}$ & $\begin{array}{l}20-25 \% \text { per unit of GDP } \\
\text { from } 2005 \text { levels }\end{array}$ \\
\hline Indonesia & $\begin{array}{l}\text { Kyoto } \\
\text { GHGs }\end{array}$ & $26-41 \%$ below BAU \\
\hline Brazil & $\begin{array}{l}\text { Kyoto } \\
\text { GHGs }\end{array}$ & $36-39 \%$ below BAU \\
\hline
\end{tabular}

39. However, given that structural reforms inevitably raise important transitional issues, there is no single, straightforward path to the implementation of a desirable policy mix. In the case of a reduction in the use and emission of carbon, the scale of the requisite resource shifts, as well as the protracted time involved, make it particularly difficult to achieve a 'first-best', economically-optimal, lowest-cost, transition - such as depicted in Figure 1 by the movement around the economy's production possibility frontier (path 1). ${ }^{19}$ Were production to follow that path, the economy would be using all its resources, all the time, and in the most economically efficient way.

40. In practice, most transitions fall short of the optimum, for a number of reasons. Price signals, the principal inducement in a market economy for resources to flow from one use to another, may be distorted. Resources may be sticky, unable to move smoothly from one use to another. Firms may be slow to recognise the implications of making the transition, and initially under-invest. Perhaps more importantly, the process usually involves winners and losers, which prompts resistance. Political-economy considerations are indeed the main obstacle to moving immediately to the lowest-cost policy path. Put differently, the representative welfare function that policy makers seek to maximise in the real world will most likely be political rather than social (Helm and Hepburn, 2009).

41. The challenge for policymakers is therefore to choose among various alternative, feasible policies, such as those depicted in Figure 2, that have the potential to reach the mitigation objective, albeit at greater cost than the optimum. For example, they must build a constituency for the package of (secondbest) policies that will come closest to the optimum. The less favourable the trade-off between economic efficiency and political feasibility, the larger is the area between the production possibility frontier and the chosen policy path, and therefore the higher the cost of the latter. In practice, even achieving a 'second' best policy requires fulfilling many technical and political requirements (Box 2). 
Figure 1. First-best, economically-optimal, lowest-cost, transition path (path I)

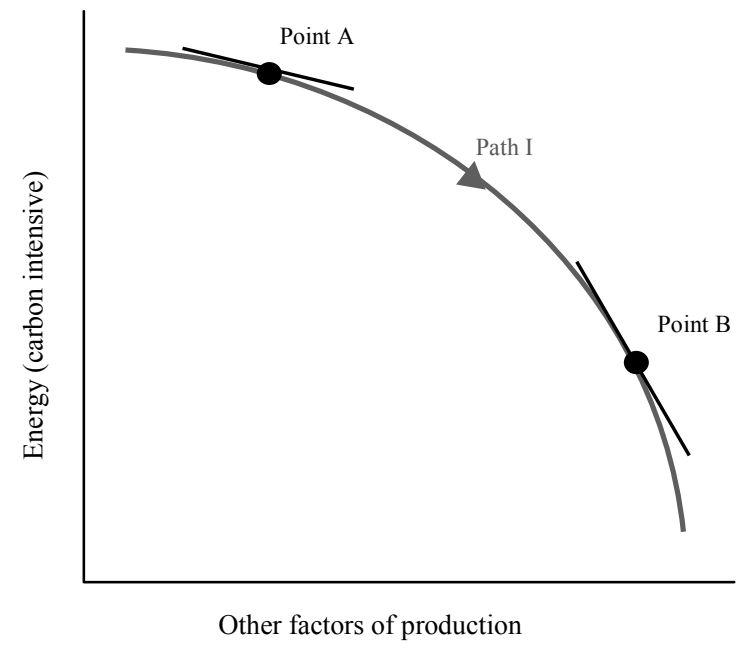

Figure 2. Feasible, sub-optimal cost transition paths (paths II to IV: from low to high cost)

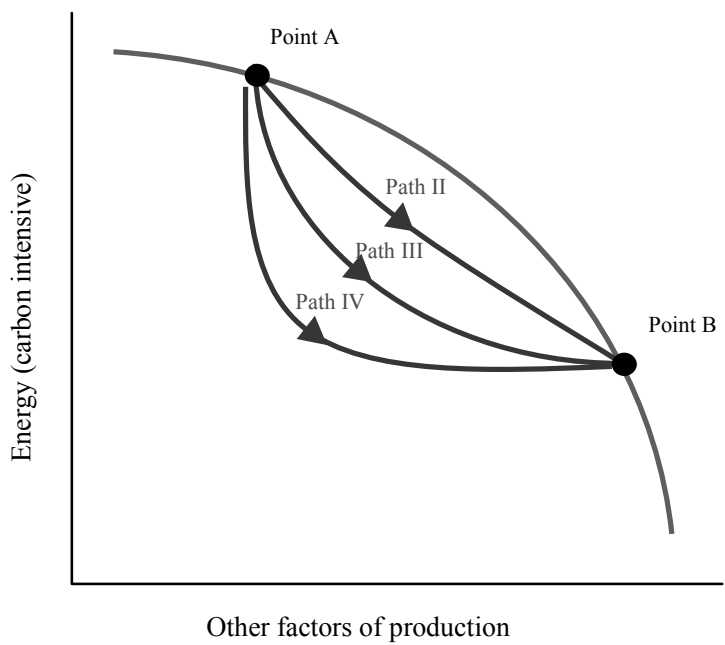

\section{Box 2. Characteristics of low-cost policy design}

A clear price mechanism at the core. Almost all economists agree that the price mechanism needs to be at the core of climate change policy, with carbon priced at its social cost. Market mechanisms are effective in changing the quantity (of greenhouse gases) emitted, one reason being that they leave open the question of how, when, or where this is done. Moreover, prices allow for equalisation of marginal abatement cost across all emission sources. And, they can also maximise fiscal revenues.

A mix of policy instruments. In practice, market mechanisms are seldom used in isolation. Different 
instruments are needed to overcome the different market and political obstacles and/or different emissions sources (OECD, 2007). Indeed, in the presence of multiple market failures market mechanisms alone are often insufficient. Asymmetric information affecting, in particular, monitoring and enforcement, leads to some emitters not responding to price signals. Economic theory offers basic insights into which of the many instruments $^{2}$, or what combination thereof, stand to be appropriate for climate change mitigation, and under what circumstances.

Comprehensive cost-benefit analysis. An ideal set of instruments are individually cost-effective per se. In modern economies it is a truism, but an important one, that 'everything is related to everything else'. If instruments are complementary, they can assist low cost implementation. Equally, however, there is a risk that their use may engender higher implicit costs of carbon. Avoiding perverse distortionary effects that reduce effectiveness by increasing the implicit cost of carbon requires a good understanding of the links and coordination with other policy areas, including those that are international. Regulatory instruments applied in conjunction with environmentally-related taxes, for example, can unnecessarily restrain the flexibility for polluters to find cost-effective abatement options offered by a tax.

Instruments applied as widely as possible. Incomplete coverage of carbon pricing mechanisms, whether in terms of countries, industries, emissions sources, or gases - increases the cost, and decreases the effectiveness, of mitigation action. OECD estimates suggest that:

- Exempting energy-intensive industries from policy action increases the costs of achieving the target by over $50 \%$, based on meeting an illustrative 550 ppm CO2eq by 2050 (see OECD, 2009a; Chapter 3)

Remove policies that create perverse incentives and distortions. Any policy that encourages emissions, whether through subsidisation or exemptions, raises the overall cost of mitigation, runs contrary to the "Polluter Pays" principle, and often benefits higher-income earners disproportionately. 'Special provisions', often aimed at buying off specific interest groups, increase political acceptability, but increase costs and encourages rentseeking behaviours.

- Calculations by the OECD suggest that the multilateral removal of fossil fuel subsidies alone would cut GHG emissions globally by around $10 \%$ by 2050 relative to "business as usual" (OECD, 2009a; chapter 4). While the estimated subsidies underpinning this scenario are found mostly in non-OECD countries, the fossil-fuel industry in OECD countries is also subsidised in the form of tax breaks and other benefits.

1 Including that of instrument choice

2. Taxes, trading schemes, standards and regulations, technology support policies etc.

\section{Political-economy challenges in implementing a cost-effective mitigation policy mix}

42. One of the main challenges with mitigation policy is that the instrument that ought to be applied most widely - the pricing of carbon - is also the most difficult to implement from a political perspective. Indeed, both subsidies and command-and-control regulations have been used more widely to address environmental externalities, even though their cost-effectiveness is considered to be generally much lower. To some extent, this may reflect the general aversion to taxes, and a misperception as regards the notion that economic agents can buy rights to pollute. A more compelling reason is that, although the overall cost of non-price measures may well ultimately exceed that of pricing instruments, it tends to be more diffuse and less visible to the wider public. This is particularly true for subsidies, where the cost is ultimately 
borne by taxpayers (including future ones with no political voice). It is somewhat less obvious for command-and-control regulation, given that they can be expected to raise firms' operating costs, but they are still less visible to voters. Firms, especially large ones, may find it easier to deal with compliance costs (or use their informational advantage to lobby for lax standards) and may also find a benefit in the form of an additional barrier to entry for eventual competitors. As for smaller firms, while they are more likely to lack the resources to comply effectively they may have less political clout to lobby against regulation.

43. Faced with strong and persistent opposition to the implementation of taxes or permit systems, policymakers may be tempted to treat alternative instruments as a substitute for, rather than as a complement to, pricing in pursuit of their climate change mitigation objectives. Yet, numerous studies have shown that none of these alternative policies can succeed without some form of carbon pricing (OECD $a$, 2009, Buchner and Carraro, 2005). This reflects an absence of incentives on the part of households and firms to search for less carbon-intensive sources of production and consumption in the absence of any opportunity cost of carbon. There is also the risk that directed subsidies or technology standards lead to excessive long-term investment being trapped in technologies that turn out to be relatively inefficient.

44. One of the key objectives is therefore to identify a range of actions that can best contribute to overcome the resistance to pricing policies. This includes providing estimates of the cost of alternative policies in terms that can be directly compared with those of carbon pricing, identifying the main losers from pricing measures, including distinguishing between individuals (e.g. distributional impact) and industries (e.g. competitiveness, stranded costs), and identifying the least-cost options to ease the impact of policy, especially for those most affected.

\subsection{Establish the cost of policy alternatives in a way that is directly comparable}

45. As mentioned above, the stronger political appeal of instruments such as regulatory standards and subsidies for clean technologies owes in large part to the reversal of the forces usually acting against reform: with subsidies and, to a lesser extent regulation, the costs tend to be more diffuse (to the general taxpayers or end-consumer), while the benefits are more concentrated (in the case of subsidies). To facilitate the adoption of pricing policies it is therefore important to make clear the costs (and benefits) of alternatives, preferably in terms that are as directly comparable as possible. There are several examples, notably in the area of subsidies, where this may be relatively easier to do. For example, various estimates of the implicit price of biofuel subsidies expressed in dollars per $\mathrm{CO}_{2} \mathrm{eq}$ avoided have underscored the high cost of such measures (Table 2). Similarly, other studies have shown that the implicit carbon price of subsidising the large-scale deployment of renewables through feed-in tariffs or renewable portfolio standards can also be high. ${ }^{20}$ These could be generalised, taking as examples the frameworks developed at the OECD to measure the cost of various agricultural support measures. Of course, to the extent that the difference in costs can be motivated by separate objectives that the policies aimed to achieve, this should be recognised in establishing the comparison. On the other hand, one reason for favouring the pricing instrument is that subsidies are arguably more vulnerable to rent-seeking and capture, with implications on the effectiveness of the policy that are not necessarily well reflected in simple cost measures. In any case, a direct comparison based on a relatively simple measure can be helpful in informing the wider public about the real costs of the alternative policy choices.

20 See McIlveen and Helm (2010) for a recent example of cost-benefit comparison of different carbon abatement policies in the United Kingdom. See also "Green certificates and the effect on the climate" (www.ssb.no/english/research/articles/2009/12/1259932098.4.html). 
Table 2. Subsidies to ethanol and biodiesel per ton of $\mathrm{CO}_{2}$ equivalent avoided in selected OECD countries, lower bound estimates, 2006

(\$US per ton of $\mathrm{CO}_{2}$ eq)

\begin{tabular}{|l|c|c|}
\hline & & \\
\hline & Ethanol & Biodiesel \\
\hline United States & 300 & 250 \\
\hline European Union & 700 & 250 \\
\hline Australia & 400 & 150 \\
\hline Canada & 250 & 250 \\
\hline Switzerland & 300 & 250 \\
& & \\
\hline
\end{tabular}

Source: Steenblik (2007)

46. Compared with subsidisation, the cost of climate change regulation is arguably more difficult to establish, in particular in the case of technology standards or norms. Indeed, relatively few studies have looked at the broader implications of environmental regulation on performance, whether at the firm or sector level, especially outside the United States. ${ }^{21}$ A number of countries (e.g. Australia) require that the benefits and costs of all proposed policy/regulations be assessed and made public. Also, substantial efforts have been made, notably at the EU level, to assess the compliance costs of regulation - including environmental regulation - but much remains to be established about the impact of regulations on productivity, as well as on their cost-effectiveness in the short and medium term.

\subsection{The uneven distribution of costs and benefits of pricing instruments is raising concerns}

47. Raising the relative price of such a fundamental input as carbon-intensive energy on the scale required has never been undertaken before. ${ }^{22}$ For this reason, policy made in the name of climate change stands to impact the social and economic fabric of nations more fundamentally than have previous environmental policies. Furthermore, as is often the case with deep reforms, the costs and benefits of carbon pricing policies are unevenly distributed across countries and individuals (including across generations). Though policy is ultimately expected to create more winners than losers, those who stand to lose the most will naturally mobilise most effectively, in opposition. And, providing appropriate compensation is both costly and has proved difficult in practice. By contrast, given the distant and diffuse nature of benefits, identifying and mobilising the winners is far more difficult. In addition, studies based on surveys of preferences indicate that people's "willingness-to-pay" for climate change mitigation depends not only on estimates of their own individual benefit but also on their perception of the distributional consequences of policy, including in terms of the sharing of mitigation costs within and across countries (Cai, Cameron and Gerdes, 2010).

22

See Gray (2002) for a collection of not-so-recent empirical studies on the economic costs of environmental regulation.

There have however been more limited precedents, notably the taxation of motor fuels in many countries, and the policy-induced reduction of $\mathrm{NO}_{\mathrm{x}}$ emissions in the United States. 
48. Losers also tend to evaluate expected payoffs relative to an inappropriate benchmark. If the status quo is, or is likely to be, unsustainable, as in the case of climate change, evaluating expected payoffs from reform against the status quo is inappropriate. Nevertheless inappropriate benchmarking continues because there is little to no recognised danger of imminent breakdown if reforms are not implemented. Opponents can simply defend the status quo without feeling the need to put forward an alternative. ${ }^{23}$

49. More importantly, the implication of domestic pricing measures to address climate change raises legitimate concerns of competitiveness among firms and income distribution among households, which can in turn be exploited effectively by opponents. Arguments pertaining to the (limited) effects at the level of the economy as a whole are likely to carry little weight at the level of the firm and of the individual, insofar as costs will be greater for some than others. Successfully identifying, quantifying, and addressing these concerns is arguably the most crucial element for policymakers to get right. This is all the more so given that resistance by both households and firms is also driven by fears that, in the absence of international coordination, their efforts to reduce emissions will be largely offset by rising emissions in other countries, not least through carbon leakage effects.

\subsubsection{Concerns about leakage and competitiveness}

50. Even though they are to some extent related, leakage and competitiveness effects are of a slightly different nature. Consider first the leakage issue. Given the relatively high degree of trade-exposure of energy intensive industries around the world, leakage effects can be potentially significant for one country (or a small group of countries) acting alone, but they have been found to diminish rapidly as the group of countries imposing emission caps expands.

- For example, model-based estimates by the OECD suggest that, if the EU were to cut emissions unilaterally by $50 \%$ by 2050 (relative to 2005), just under $12 \%$ of this abatement would be 'wasted' through leakage. And, if similar policies were applied in all advanced (Annex 1$)^{24}$ countries, the 'waste' would be less than 2\% (OECD 2009a). ${ }^{25}$

- These results are corroborated by another study, which finds that if the European Union and the United States were to decrease emissions by $17 \%$ from 2005 levels by 2020 , the resulting additional increase in developing-country emissions would still be only about 1\% (Mattoo et al., 2009). Some production would migrate, but the net increase in emissions in poor countries would be small.

51. Thus model-based analysis suggests that the political importance of carbon leakage far exceeds its economic significance. If these findings could be communicated persuasively, voters in countries that contemplate the introduction or extension of emission caps and carbon pricing could at least be reassured

23

The case of pension reform is an example. While in several countries the demographic arithmetic had for years clearly shown the unsustainability of many pension systems, there has long been, until perhaps fairly recently, much resistance to raising the age of retirement even broadly in line with longevity.

24

Annex I countries are those which under the Kyoto protocol have committed to reduce their emission levels of greenhouse gasses to targets that are mainly set below their 1990 levels. There are 41 Annex I countries (mostly advanced economies) and the European Union is also a member.

Leakage occurs through two channels. One is the competitiveness channel and the associated relocation of production towards countries that do not impose emission caps; and the other is the world energy market or price effect, i.e. the reduction in energy demand in countries imposing emission caps contributes to lower fossil-based energy prices, which stimulates energy demand and emissions elsewhere. The latter channel is estimated to have a limited impact even when the group of countries taking action includes most advanced economies. 
that their efforts to reduce emissions would not be in vain. However, this may carry only limited weight insofar as voters understand that economies of other countries will be able to "free ride" on their actions, and that the sectors impacted may have a political influence that may also exceed their economic significance.

52. Furthermore, this would not be sufficient to address competitiveness concerns, given that the latter arise mainly from differences in carbon prices across countries. A "level playing field" not only requires action by a sufficiently large coalition, but also that carbon markets be integrated - or taxes be harmonised - so that a uniform carbon price applies, at least at the industry level. ${ }^{26}$ In the absence of a uniform price, the impact on sectoral competitiveness stands to be the greater:

- The lower the ability of the firms within the sector to pass on the costs. This depends on the price responsiveness of demand, market structure, the geography of the sector or market and, most importantly, international competition;

- The lower the scope for substitution in production technologies. In the short term there are few energy input substitutes for energy-intensive firms; and

- The higher the energy intensity of, and pollution by, the sector.

53. Fears of being disadvantaged will be particularly strong in the most polluting, most energyintensive, internationally tradeable sectors. With many likely to be politically powerful, and highly motivated in their efforts to maintain the status quo, policymakers will need to pay particular attention to such sectors. However, experience may provide little guidance as to how significant the concerns for these sectors might be. To date, for example, environmentally-related taxes have not been identified as causing significant reductions in the competitiveness of any sector: but this has been largely because the countries applying these taxes have usually provided for total, or at least partial, exemptions to energy-intensive industries. The OECD/EEA (European Environment Agency) database on instruments used for environmental policy shows that environmentally-related taxes have to date been levied almost exclusively on households and the transport sector (see OECD, 2010 for a review of application to other sectors).

54. The EU emission trading system (ETS) represents one major pricing mechanism covering various trade-exposed, energy-intensive industries. Given that the system has been in operation only for a few years, it may be premature to draw firm conclusions from its experience. But one recent study suggests that the pricing of carbon has had no perceptible effect on the competitiveness trends of specific EU industries such as cement, and iron and steel (Ellerman, 2009). Likewise, an empirical analysis of the Climate Change Levy in the United Kingdom suggested that it has had no significant (adverse) impact on energy intensive firms (OECD, 2010). One reason is that the price of carbon is just one among a large number of factors affecting cross-border competitiveness. This has been especially so given that (so far) carbon prices have been relatively low (although this seems bound to change in the future) and the effect of far more stringent environmental policies remains largely unknown. One recent study looking at the impact of environmental regulation on the comparative advantage of specific EU industries relative to those operating in China has found a mixed picture across sectors, but no clear evidence of a relocation of likely to differ across countries. For example, model-based simulations suggest that if the Annex I countries were each to cut their emissions by $50 \%$ by 2050 relative to 1990 , using separate price instruments, carbon prices could vary from less than $\$ 100$ per tonne of $\mathrm{CO}_{2}$ eq in Russia to around $\$ 600$ in Canada (OECD, 2009a). 
polluting industries in poorer countries (the so-called pollution haven effect) once the influence of factors such as labour costs are controlled for. ${ }^{27}$

55. On the other hand, potential negative impacts on the international competitiveness position have been demonstrated in some recent OECD case studies of the cement and steel sectors.

- In the cement sector, the model simulated a $\mathrm{CO}_{2}$ tax, equivalent to a $\mathrm{CO}_{2}$ Emission Trading Scheme with auctioned allowances, without revenue recycling, in Annex I countries except the United States and Australia, at 15 Euros per tonne - entailing a (significant) decrease in $\mathrm{CO}_{2}$ emissions in these countries of around $20 \%{ }^{28}$. The impact on cement production in these countries was estimated to be $-7.5 \%$ in the medium term, due to a cut in their domestic consumption level and a loss in competitiveness. The corresponding leakage rate was estimated to be around $25 \%$ and $15 \%$ in the medium- and long-term, respectively ${ }^{29}$ (see OECD, 2005).

- In the Steel industry, model simulations have suggested that an OECD-wide carbon tax of $\$ 25$ per ton of $\mathrm{CO}_{2}$ would reduce OECD steel production significantly, by $9 \%$, ${ }^{30}$ with some substitution towards more scrap-based production. Recycling revenues back to the sector was found likely to reduce the impacts on the sector significantly, perhaps limiting the decline to under $1 \%$. In the longer term, however, the negative impacts on the sector in total might be larger, as or when new capacity shifts to non-OECD regions (see OECD, 2003).

56. A decline in the production of these sectors should not by itself be a source of preoccupation insofar as a reduction in emission is the objective. The concern arises when production is merely shifted to other locations, along with the underlying emissions. In any case, even within sectors the distribution of cost is likely to be uneven across firms, prompting those most affected to lobby harder against pricing policies. For example, one index of a firm's relative carbon efficiency shows that, in a sample of European airlines, emissions in relation to revenue ranged from $64 \%$ above the average for one company to $10 \%$ below for another. ${ }^{31}$ More generally, the effects on firms' relative valuations from having to pay for their emissions stand to be substantial.

57. Clearly, from an economic efficiency point of view, concerns about leakage and competitiveness would be best addressed through an international agreement that would ensure the participation of all major emitters to global GHG emissions efforts, within a framework that would foster equalisation of carbon prices across regions (OECD, 2009a). However, considering that such agreement may not materialise anytime soon, countries which wish to implement domestic pricing mechanisms may need to consider alternative measures to alleviate these concerns in order to gain sufficient domestic popular support. Among the measures considered, the exemption of specific sectors or emission trading systems with free allocation of permits have generally been favoured by industries, while tariffs on the $\mathrm{CO}_{2}$ content

See Marconi (2010). The author finds that notwithstanding more stringent environmental control, EU countries have on average maintained or improved their comparative advantage in both water-polluting (paper and agro-based sectors) and air-polluting industries (basic metal and chemicals), but lost competitiveness in cleaner sectors such as machinery and fabricated metal.

Through a quicker penetration of energy-efficient technologies, a decrease in the rate of clinker (the $\mathrm{CO}_{2}$. intensive input) in cement, a quicker switch to low carbon fuels (gas, waste and wood fuels), and a decrease in cement consumption.

A result in the upper range of leakage estimates presented in the IPCC third assessment report .

The reduction was greater for heavily polluting integrated steel mills (12\%) than for scrap-based mini-mills (2\%).

See the website of Trucost for sources of information. 


\section{$\mathrm{ECO} / \mathrm{WKP}(2011) 56$}

of imports (border tax adjustments) appear to have more traction vis-à-vis individuals or households, who are more concerned by leakage effects (and equity issues - see below).

58. The respective economic drawbacks of these measures have been documented (de Serres, Murtin and Nicoletti, 2010; Smith, 2008). The exemption of trade-exposed industries can significantly raise the cost of achieving mitigation objectives, imposing an excessive burden on other sectors. The free allocation of permits to exposed firms provides them with compensation (or rent) for the impact of carbon pricing on their existing capital stock (and therefore asset value), but is ill-suited to addressing the competitiveness concern per se. The reason is that if permits are allocated on the basis of historical emissions (grandfathering), industries remain fully exposed to the price signal, so that incentives to relocate production abroad are the same as if permits were auctioned (Hood, 2010). Alternatively, if permits are allocated on the basis of current and future production levels - equivalent to a production subsidy - this helps to preserve competitiveness, but only at the cost of diminished incentives to reduce emissions. ${ }^{32}$ Also, while governments forego revenues at a time when it is much needed, industries with significant market power receive a huge windfall profit if they get most permits freely. ${ }^{33}$ Moreover, such windfall profits are more likely to benefit high-income individuals.

59. The free allocation of permits has been instrumental in overcoming resistance to the introduction of the EU ETS. However, two phases and several years later, the proportion of permits freely granted is set to remain high for the period 2013-2020, which raises efficiency and equity concerns. ${ }^{34}$ Furthermore, in both Australia and the United States, attempts by the respective governments to introduce nation-wide emission trading systems were unsuccessful, notwithstanding substantial efforts to limit the impact of the policy - at least in the initial years - through compensation mechanisms such as free allocation and the use of credit offsets. ${ }^{35}$

60. Border tax adjustments (BTAs) have so far not been used in practice, even though they arguably have received most attention. In contrast to the other measures, BTAs directly address the competitiveness concern by imposing a similar carbon price on foreign producers. In that sense they can help preserve the

32 In principle, even under an output-based allocation, firms still have an incentive to improve production methods so as to reduce emissions and free permits. However, with more than enough permits to cover their emissions, the extent to which firms internalise the opportunity costs in their management strategy is not clear, especially if investing in permits trading represents one business opportunity among many, and that this is far from their main line of businesses.

Such overcompensation has been observed in the first phase of the EU ETS (Hepburn et al., 2006). One recent study shows that the proportion of free permits necessary to provide compensation varies according to the elasticity of demand, the number of operators competing in the market, and the size of the targeted reductions (Guesnerie, 2010). Assuming a 30\% reduction in emissions and a high demand elasticity, the share of free permits would need to be $30 \%$ if only three firms operate but would fall to $10 \%$ if the market is shared by 10 firms. Another study, focusing on the US electricity sector, suggests that $20 \%$ of free permit allocation would be sufficient for all industries to be fully compensated (Goulder, Hafstead and Dworsky, 2009).

Under the plans for the third phase, free allocation rules will be more targeted to trade-exposed industries, and therefore will largely exclude industries such as power generation which have gained huge windfall profits during the second phase.

In Australia, a tradable permit bill was rejected just before the Copenhagen conference in late 2009, and has been put on hold until at least 2012. However, following elections which led to a coalition government, a proposal for a carbon tax to be introduced by mid-2012 has been put to parliament. The tax is intended as an interim solution until a broader consensus is established in favour of a tradeable permit system. In the United States, the Waxman-Markey cap-and-trade bill was approved by the House of Representatives in June 2009, after which it was passed to the Senate, where it has been abandoned even after many revisions. 
environmental integrity of domestic action by neutralising the trade-related source of carbon leakage. However, the benefit in terms of environmental integrity would most likely come at the expense of further output losses for both carbon-intensive and other industries due to the higher cost of imported intermediate inputs. $^{36}$

61. Perhaps the most significant obstacle to a BTA is one of practical application. Such schemes are technically difficult to implement, and tend to be administratively heavy. Differences in production methods, efficiencies, and energy generation both complicate matters and create the potential for distortion; there is for example currently no agreement on how to calculate the embedded carbon content in a given manufactured good. As a result, even if the measure cannot on its own be legitimately contested on protectionist grounds, the modalities of application could easily lead to protracted discussions in international bodies, in particular the WTO. Indeed, the legality under GATT/WTO rules of applying BTAs to energy taxes is currently uncertain, because the issue of how to treat inputs (such as energy) that have not been physically incorporated into a product, has never been formally considered by a GATT/WTO dispute panel. ${ }^{37}$ Yet, if BTAs were to be employed, it would be essential, in order to minimise the risk of retaliation, to do so only following adjudication by an independent international body charged with ensuring a level playing field. In such a case it is possible that countries facing a BTA on their export market might take the lead and impose a carbon-based tax on their exported goods so that they can at least collect the revenues.

\subsubsection{Distributional concerns}

62. Concerns relating to a regressive impact on income distribution are also valid. Most studies find that environmentally-related taxes, especially energy taxes, tend to have a regressive impact on the income distribution of households. ${ }^{38}$ The primary reasons for this regressivity are:

- Poorer segments of society tend to spend a high fraction of income on fossil-fuel-intensive products.

- The less well-off stand to place greater value on food and shelter than on environmental improvement - even though the two will in practice be related. New, more energy-efficient,

36 See Burniaux, Chateau and Duval (2010) for recent estimates of BTA effects based on general equilibrium model simulations. While the net impact of the BTA on output from energy-intensive industries is generally reckoned to be negative, the estimated net welfare effect is more often positive. However, in both cases the estimated effects of introducing a BTA are small relative to pricing carbon domestically only. The more favourable result on welfare (relative to output) arises because the introduction of a domestic carbon price creates a distortion in the relative price between imported and domestic goods, which the BTA can eliminate. Also, estimates based on the sector-specific analyses mentioned above suggest that BTAs could actually help reduce output losses associated with a carbon tax in the cement and steel sectors (OECD, 2005, 2003).

At the same time, the WTO has in the past ruled in favour of the United States, which imposed a ban on imports of shrimps and shrimp products from Asia on grounds of protection of marine turtles. The WTO ruled that countries are entitled to take commercial measures to protect the environment (in particular when the concerns is with the health of people or animal or the preservation of vegetation) and endangered species (Howse, 2002).

38 See in particular Fullerton (2008) and Grainger and Kolstad (2010). At the same time, the impact of environmental policies on income distribution should be balanced against the distributional effects of the benefits. Insofar as low-income households usually live in areas more exposed to air pollution, they can be expected to also benefit proportionately more from pollution abatement. However, empirical analysis on this is more difficult to come by. 
technologies are often expensive, raising the relative cost of power and housing for lower-income households.

- Abatement technologies are often capital-intensive: raising demand for capital relative to labour stands to lower real wages, hurting low-income households in particular.

- Pollution permits handed out to firms bestow scarcity rents on firm owners, who tend to be the more well-off individuals.

- Any house-price capitalisation benefits from environmental improvements, such as to air quality, are gained by landlords rather than those who rent.

63. Accurately calculating the degree of regressively is however problematic, because much depends on method and measurement. First, calculations at the per capita level suggest a far greater incidence of regressivity than calculations made at the household level. Second, assumptions are often far from being realistic. It is often assumed, for simplicity, that costs are fully passed on to consumers, and that price increases do not alter the choices made by consumers and producers (no substitution). A recent US study has found that the degree of forward shifting (leading to higher consumer prices) or backward shifting (leading to lower factor returns) may differ substantially across type of fuels and market conditions, and that this has a significant impact on the degree of regressivity (Metcalf, Mathur and Hassett, 2010).

64. Third, studies tend to measure only the direct burden. Not all channels through which policy has distributional effects are considered, and many of these are indirect. For example, towns whose predominant occupation involves just one industry, such as logging or mining, can be affected severely, or even destroyed, by policy. The value of the industry-specific human capital lost in the reduction or decline of such an industry is often not re-employed elsewhere at zero cost, as it is often presumed. Furthermore, capitalisation effects that provide large one-off gains or losses are often among the most redistributive effects of policy, but they are also difficult to take into consideration. More generally, both the benefits derived from the environmental improvements (which may accrue disproportionately to low-income households) and the costs borne by factors of production are often overlooked (Metcalf, Mathur and Hassett, 2010).

65. Finally, much also depends on policy itself. For example, price effects, whether imposed through a tax or through a tradable permit scheme, are more or less equally regressive. However, the incidence of applying a carbon price to final energy consumption only has been found to be twice as regressive as a price applied to all $\mathrm{CO}_{2}$ emissions (Grainger and Kolstad, 2010). Perhaps more importantly, the way in which policy is implemented can do much to alleviate regressivity. Targeted revenue recycling can be used for transfers and tax cuts to help some of the affected households. ${ }^{39}$ However, a plan to introduce a carbonbased tax on domestic energy and road fuels in France was withdrawn notwithstanding a strong commitment to use all the revenues to compensate those most affected. ${ }^{40}$

Calculations made by the US Congressional Budget Office suggest that the spending plans in the WaxmanMarkey bill passed in June 2009 stood to offset virtually all of the (established) regressive aspects of the permit scheme. This is the case also for the two main alternative cap-and-trade proposals discussed in Congress (Kerry-Boxer, Cantwell-Collins), both of which contain provisions that would have made the carbon pricing policy progressive, even under the assumption that all costs are passed on to consumers (Metcalf, Mathur and Hassett, 2010).

The tax would have exempted 1000 of the biggest industrial emitters already covered by the EU-ETS, and responsible for just over $90 \%$ of industrial emissions. It would have added nearly 5 euro cents to a litre of petrol, and increased gas bills by $7 \%$. However, the proposed tax was ruled unconstitutional. 


\subsubsection{Summing-up}

66. What these findings underscore is that competitiveness and distributional concerns can and should be addressed explicitly, as part of the policy process, even though doing so may not be sufficient to gain popular support for pricing measures. Failure to do so will almost certainly reinforce opposition.

67. If 'special provisions' are to be invoked, instruments must be chosen and used with great care, so as to limit the burden and maintain abatement incentives. Inappropriate use of instruments may be costly, may trigger rent-seeking behaviour, and blunt the effectiveness of the reform itself. In principle, much can be done to address distributional concerns through the recycling of revenues:

- If low-income households are to be compensated, direct measures should be used which do not unduly distort the price signals, but which nevertheless reduce the negative impact of the (environmental) tax. Such concerns are ideally addressed by approaches that do not undermine the incentives to switch to cleaner consumption practices (e.g. by reductions in other taxes, or through social security systems).

- At the same time, recycling the revenue from a carbon tax and using it to lower another unrelated tax - a tax applicable to a firm's labour force for example - can improve the relative competitiveness of labour-intensive firms. ${ }^{41}$

\subsection{Issues involved in choosing and designing second-best policy options}

68. Securing politically-feasible, least-cost policy involves overcoming political resistance without providing excessive exemptions and compensation for those who lose out, so as to preserve the environmental integrity of the policies. Tactical concessions to potential losers, if designed and implemented with care, need not compromise the overall thrust of the reform. But scaling back existing 'special provisions', and applying instruments in the absence of new special provisions, can be particularly challenging.

\subsubsection{Selecting pricing instruments and flanking measures to achieve political acceptance}

69. Policymakers have to date often opted for tradable permit schemes (ETSs) rather than taxes as their favoured primary instrument for pricing carbon. ${ }^{42}$ From a strict cost-effectiveness perspective, the two instruments are largely equivalent, although it has been argued that in the case of climate change mitigation, taxes may have a slight advantage, given that the cost of adjusting the price will be lower than that of adjusting quantities. ${ }^{43}$ Taxes also have the advantage of being simpler and cheaper to implement, and they have also been used more widely in the broader environmental arena. ${ }^{44}$ The main reasons for favouring permits as a means to introduce pricing are therefore more of a political-economy nature:

\footnotetext{
$41 \quad$ Assuming that the taxes reduced are more distorting than the environmentally-related taxes introduced.

Notable exceptions include the Nordic countries, which have introduced carbon-based taxes.

The reason for this is that incremental changes to the target level of GHG emissions (quantity) can be costly for firms in the short term, relative to the benefits in terms of avoided climate related damages (Weitzman, 1974).

There are around 375-odd environmentally-related taxes, and around 250 environmentally-related fees and charges, in operation in the OECD countries (OECD, 2006). The revenues they have raised are estimated to be of the order of $2-2.5 \%$ of GDP. About $90 \%$ of these stem from taxes on motor vehicle fuels and motor vehicles.
} 
- That tradable permits are not called a 'tax' seems to reduce political hostility, although perhaps in part for the disreputable reason that such schemes are seen by potential opponents as offering greater potential for capture.

- Such schemes also keep financial transfers relatively 'anonymous', as they obviate the need for direct transfers to the country with emissions credits from the polluter's 'national' tax revenue.

- The cost of permit schemes is less visible to consumers, even when it is ultimately borne by them.

- It may be easier to build a constituency with permits, given that the parties involved quickly become "stakeholders". Considerable success has been achieved with permit systems in other areas, notably in the United States, where approaches based on property rights and tradable quotas have deeper roots than elsewhere.

70. An additional advantage of cap-and-trade systems in the eventuality of an international binding agreement is that they stand to facilitate the gradual linking of scattered carbon markets, and foster the emergence of a uniform carbon price. Owing in particular to their built-in financial transfer mechanisms, permit systems are better suited than taxes for cases where co-ordination across jurisdictions is required for maximum efficiency. However, the currently bleak prospects of an international agreement raise the question as to how much weight should be given to these considerations in the choice of a domestic policy strategy.

71. So far, policymakers have also chosen to address the competitiveness and equity concerns mainly through a mixture of exemptions, free permit allocation, and recycling of revenues (in the case of taxes). As mentioned above, the approach based on free allocation of permits appears to be reaching its limit. There is a widespread perception - warranted or not - that ETSs are not working as well as expected. Incrementalism and concessions, even if well intentioned, have produced policy that is often cumbersome, expensive, and open to regulatory capture.

72. Partly as a result, there seems to be little political momentum in favour of broadly-based pricing mechanisms to cut GHG emissions. This raises the question as to whether the commitments made at Copenhagen and Cancun to cut emissions by 2020 can be achieved and, if so, at what cost? In this context, some have argued that the pressing need for raising fiscal revenues following the crisis may provide the best window of opportunity to push for the type of instrument, such as a carbon tax, that does so in the least distorting way (Nordhaus, 2010, Mcllveen and Helm, 2010). Clearly, the prospect of substantial revenues should appeal to governments confronted with huge public finance difficulties.

73. However, it is not clear that the case for higher fiscal revenues, especially in the form of new tax instruments, has become that much easier to defend politically, notwithstanding the pressing need for budgetary consolidation in many OECD countries. Governments have so far sought to raise revenues by closing existing tax breaks. Furthermore, although existing ETS-type schemes are still far from perfect, the fact that they are being used in one form or another in a large number of jurisdictions (Hood, 2010), and that much has been learned from their experience - not least from the EU-ETS - suggests that the benefits of a sudden change to a tax, even if it were economically more efficient, would need to be balanced against the costs. Finally, even if there was a window of opportunity to introduce taxes at the domestic level, the possibility of moving towards harmonised carbon taxes at the international level remains unlikely.

74. More generally, to justify a revenue-raising pricing mechanism - be they carbon taxes or auctioned permits - on fiscal consolidation grounds would imply that the scope for using free allocation or revenue recycling to address leakage and competitiveness concerns would be limited, leaving some form of 
border adjustment as the main option (either through a BTA, or a requirement that importers purchase emission allowances as well).

\subsubsection{Designing non-pricing policies to minimise rent-seeking behaviour and risks of capture}

75. Regardless of whether the barriers to broadly-based carbon pricing can be overcome in the near term, policies aimed at directly supporting the development and/or deployment of low-carbon technologies (including those aimed at increasing energy efficiency) are likely to be part of the policy mix for climate change mitigation. One reason is that many countries have set ambitious targets for themselves in terms of low-carbon technology diffusion, notably in the energy and transport sectors. One motivation for supporting R\&D investment in low-carbon technologies is that, while they are needed to reduce future abatement costs, general innovation policies are unlikely to be sufficient to promote their development, even given clear price signals. ${ }^{45}$ Directed support for R\&D in clean technologies is thus viewed as necessary to overcome market size and learning-by-doing effects, which favour continued R\&D investment in existing, more carbon-intensive, technologies (Acemoglu et al., 2009). However, considering that the need to support specific technologies raises the risk of capture and locking-in effects, it is important that policy be designed so as to minimise the resulting inefficiencies.

76. In the absence of a broadly-based and strong carbon price signal, many governments have also employed different policies (not least subsidies) to encourage the large scale deployment of low-carbon technologies, both in the energy and, to a lesser extent, transport sectors. There again, experience has shown that once granted, support in the form of subsidies can be very difficult to withdraw even when the initial justification no longer applies. ${ }^{46}$ Therefore, subsidies should be granted for time-limited periods, and their allocation should be transparent so as to facilitate the regular and frequent monitoring of their effectiveness. More generally, policies can be chosen with a view to minimising the risk of rent-seeking behaviour and regulatory capture by specific industries. For example, policies that leave some flexibility as regards the choice of specific technology are to be preferred from that perspective. Thus, green certificates (or renewable portfolio standards) that require electricity distributors to supply a proportion of their power through renewable sources have an advantage over alternative policies such as feed-in tariffs. ${ }^{47}$ Likewise, government investment in certain types of infrastructure can facilitate the deployment of low-carbon technologies without necessarily signalling a preference for one over another. One example is the development of smart grids in electricity distribution.

\subsubsection{Continuously and regularly assessing the implementation of various policy instruments}

77. Regardless of the mix of instruments adopted, it is important that policy maintains the momentum of reform, and ensures that the path continues to be one of 'lowest feasible cost' over the duration. As time progresses and agents adapt, political resistance to climate change mitigation policy is likely to dissipate. Therefore, policymakers must be continually seeking to move the initial second-best

45 Carbon capture and storage is a good example. It could become an essential technology if the world is to remain reliant on fossil fuels for several more decades. Yet, until commercial viability can be demonstrated, subsidies stand to be needed.

For example, some of the existing tax breaks for the oil industry were granted nearly a hundred years ago, and were intended to support exploration and drilling at a time when the investment risk associated with such activity was much higher, due to rudimentary technology.

Where policies aimed at fostering the deployment of renewable energy interact with an emission trading scheme, such as is the case in Europe, they will have no impact on overall GHG emissions, given that the latter is set by the total amount of permits. The eventual emission reductions in the electricity-producing sector will be offset by higher emissions elsewhere through lower permit prices, unless government were to neutralise this effect through the purchase and withdrawal of permits from the market. 
policy mix closer to best practice. To facilitate this process, the policy set-up must be sufficiently flexible to admit changes of course while minimising the risk of facing "reform fatigue".

\section{Conclusions}

78. Achieving politically-feasible, 'second-best' climate change policies requires that policymakers get many technical and political requirements right. Successfully balancing the many conflicting pressures will, for most countries, be particularly challenging, as the structural and resource shifts required will be large, and there are few precedents. Nevertheless, this paper has summarised a number of constructive policy inferences that can be drawn from the burgeoning research on the political economy of climate change, as well as from experience with other structural policy reforms in the OECD area.

79. Central to low-cost reform is credibility of policy. Unfortunately, most OECD countries are in fiscal deficit; and confusion and uncertainty appears to have resulted in a decline in the proportion of the electorate believing that climate change mitigation is achievable, and hence that it should be treated as a priority. Ultimately, all major affected groups need to sign up for the requisite policies - government, business, employees, households, and the public at large: not having a mandate for reform enables opponents and potential losers to exploit divisions. Notwithstanding the progress achieved in Cancun, the prospect of an international binding agreement remains distant, and the failed attempts to introduce nationwide pricing mechanisms in a number of countries serve as a reminder that, with support fragile and volatile, the most economically-efficient policies can be politically too difficult to pursue.

80. In this context, policymakers would do well to ensure that consensus is gained within cabinet and government before moving to the wider base. For broad consensus, policymakers need to meet successfully the principal challenges which surround the politics and economics of policy. The main issues that policymakers need to address in order to implement a successful, low-cost mitigation strategy include:

- The intergenerational issue: As with most structural reforms, the cost of climate policy tends to be borne up-front, while the likely benefits stand to be realised only in the distant future. It is thus not easy to convince current voters to incur a cost to benefit a future generation, especially given that the latter is likely to be richer.

- $\quad$ The carbon leakage issue: There is always a risk of production shifting to another region with a looser emission policy. The evidence, so far at least, is that this risk may have been overstated, although such effects could build up over time.

- The competitiveness concerns: Competitiveness concerns arise mainly from differences in carbon prices across countries, which can be alleviated only through integrated carbon markets or harmonised taxes across jurisdictions, at least at the industry level. Short of that, possible measures to address competitiveness concerns include free allocation of permits or border tax adjustments, but all have significant drawbacks.

- The distributional concern: Aside from the natural resistance from those who stand to lose most from policy action, there are indications that the electorate generally attach considerable importance to the distributional consequences of mitigation policies, as they perceive them. Hence, assessing these consequences and providing effective targeted compensation measures to address specific distributional concerns without distorting the price signals, and hence the overall thrust of policy, seems fundamental. Arguably, this is also one of the most difficult politicaleconomy challenges. 
- The "counterfactual" issue: Policy should not be assessed vis-à-vis the status quo, insofar as the latter may not be regarded as a viable option. The costs and benefits of a proposed policy should rather be examined vis-à-vis what is judged would happen in the absence of policy. In the same vein, the relative cost of policy alternatives should be established in a way that is as directly comparable as possible (e.g. per ton of $\mathrm{CO}_{2} \mathrm{eq}$ abated) so as to inform the public better about the economic consequences of policy instruments whose costs are less directly visible.

- The international solidarity issue: Climate change is proving to be a difficult area for international cooperation. Earlier analyses suggest that, for most countries/regions, the domestic benefits from joining a broad coalition of countries in climate change mitigation would exceed the domestic costs. However, in all cases, the benefits from "free-riding" would likely be even higher. This adds to other complications, such as the comparability of efforts and historical responsibilities, and makes achieving a broad agreement difficult in a world that has become increasingly multi-polar. International solidarity is under strain in other areas, including trade policy and regulation of the financial services industry. 


\section{REFERENCES}

Acemoglu, D., P. Aghion, L. Bursztyn and D. Hemous (2009), "The Environment and Directed Technical Change", mimeo

Bollen, J., B. Guay, S. Jamet and J. Corfee-Morlot (2009), "Co-Benefits of Climate Change Mitigation Policies: Literature Review and New Results", OECD Economics Department Working Papers, No. 693.

Borick, C., É. Lachapelle and B. Rabe (2011), "Climate Compared: Public Opinion on Climate Change in the United States and Canada", Public Policy Forum on Sustainable Prosperity. February.

Bowen, A. and N. Ranger, N. (2009), "Mitigating Climate Change through Reductions in Greenhouse Gas Emissions: the Science and Economics of Future Paths for Global Annual Emissions", Grantham Research Institute on Climate Change and the Environment.

Buchner, B., and C. Carraro (2005), "Economic and Environmental Effectiveness of a Technology-based Climate Protocol", Climate Policy, Vol. 4, No. 3.

Burniaux, J.-M., J. Chateau and R. Duval (2010), "Is There a Case for Carbon-Based Border Tax Adjustment? An Applied General Equilibrium Analysis", OECD Economics Department Working Papers No. 794.

Chatham House (2009), International Affairs, Vol. 85, No. 6, November, Wiley Blackwell

CAE (2010), “Les effets d'un prix du pétrole élevé et volatil », Rapport Patrick Artus, Antoine D'Autume, Philippe Chalmin et Jean-Marie Chevalier pour le Conseil d'Analyse Économique, La Documentation Française, Paris.

Cai, B., T. A. Cameron and G. R. Geddes (2010), "Distributional Preferences and the Incidence of Costs and Benefits in Climate Change Policy", Environment Resource Economics, Springer.

Dellink, R., G. Briner and C. Clapp (2010), "Costs, Revenues, and Effectiveness of the Copenhagen Accord Emission Pledges for 2020”, OECD Environment Working Papers No. 22.

De Serres, A., F. Murtin and G. Nicoletti (2010), “A Framework for Assessing Green Growth Policies”, OECD Economics Department Working Papers No. 774.

Duval, R. (2008), “A Taxonomy of Instruments to Reduce Greenhouse Gas Emissions and their Interactions”, OECD Economics Department Working Papers, No. 636

The Economist, (2009), "Green with Envy, the Tension between Free Trade and Capping Emissions", 21 November.

Eskin, P. and R. Salmon (2010), "Making Reform Happen in Environmental Policy", Chapter 5 in OECD (eds) Making Reforms Happen: Lessons from OECD Countries, OECD Publishing. 
Fullerton, D. (2008), "Distributional Effects of Environmental and Energy Policy", University of Illinois, USA, Ashgate.

Garnaut, R. (2008), The Garnaut Climate Change Review, Cambridge University Press, Melbourne.

Goulder, L., M. Hafstead and M. Dworsky (2009), "Impacts of Alternative Emissions Alowance Allocation Methods under a Federal Cap-and-Trade Programme", Stanford University Working Paper.

Guesnerie, R. (2010), "Pour une politique climatique globale : blocages et ouvertures", CEPREMAP, Paris.

Grainger, C.A., C. Kolstad (2010), "Who Pays a Price on Carbon?", Environmental Resource Economics. March.

Gray, W. B. (2002), "Economic Costs and Consequences of Environmental Regulation, Ashgate.

Helm, D. and C. Hepburn (2009), The Economics and Politics of Climate Change, Oxford University Press.

Helm, D. (2010), Energy Security Policy, IIEA lecture, 3 March.

Helm, D. (2010), "Government Failure, Rent-Seeking and Capture: the Design of Climate Change Policy", Oxford Review of Economic Policy, Vol. 26, No. 2, pp. 182-196.

Hepburn, C., M. Grubb, K. Neuhoff, F. Matthes and M. Tse (2006), “Auctioning of EU ETS Phase II Allowances: How and Why?", Climate Policy, Vol. 6, No. 1.

Hood, C. (2010), "Reviewing Existing and Proposed Emissions Trading Systems", International Energy Agency, Information paper, November.

Howse, R. (2002), "The Appellate Body Rulings in the Shrimp/Turtle Case:A New Legal Baseline for the Trade and Environment Debate", Columbia Journal of Environmental Law, 27-491

International Energy Agency (2009), World Energy Outlook 2009, Paris.

Jackson, T. (2010) Prosperity Without Growth? The Transition to a Sustainable Economy, Report for the Sustainable Development Commission, United Kingdom.

Lee, I., P. Llewellyn and E. Wu (2010), "Climate Change: Growing Business Opportunities", in J. Llewellyn and L. Santovetti (2010), The Ascent of Asia, Nomura International, February.

Leiserowitz, A., E. Maibach, C. Roser-Renouf and N. Smith (2010), "Climate Change in the American Mind: Public Support for Climate and Energy Policies in June 2010", Yale University and George Mason University. New Haven, CT: Yale project on Climate Change Communication.

Marconi, D. (2010), "Environmental Regulation and Revealed Comparative Advantages in Europe: Is China a Pollution Heaven?", Banca d'Italia Occasional Paper No. 67.

Mattoo, A. et. al. (2009), "Reconciling Climate Changes and Trade Policy”, Working Paper No. 5123, November.

McKinsey \& Company, The McKinsey Quarterly (various issues). 
Mcllveen, R. and Helm, D. (2010), "Greener, Cheaper, Policy Exchange", London.

Metcalf, G.E., A. Mathur and K.A. Hassett (2010), "Distributional Impacts in a Comprehensive Climate Policy Package", NBER Working Paper No. 16101.

Nordhaus (2010), "Carbon Taxes to Move Toward Fiscal Sustainability", The Economists' Voice, September.

OECD (2010), Taxation, Innovation and the Environment, OECD, Paris

OECD (2009a), The Economics of Climate Change Mitigation: Policies and Options for Global Actions Beyond 2010, ISBN 978-92-64-05606-0, OECD, Paris.

OECD (2009b), The Political Economy of Reform: Lessons from Pensions, Product Markets and Labour Markets in Ten OECD Countries, ISBN 978-92-64-07306-7, OECD, Paris.

OECD (2007), Instrument Mixes for Environmental Policy, OECD, Paris

OECD (2006), The Political Economy of Environmentally Related Taxes, ISBN 92-64-02552-9, OECD, Paris.

OECD (2005), The Competitiveness Impact of $\mathrm{CO}_{2}$ Emissions Reduction in the Cement Sector. OECD, Paris.

OECD (2003), Environmental Policy in the Steel Industry: Using Economic Instruments. OECD, Paris.

Smith, S.(2008), Environmentally Related Taxes and Tradable Permit Systems in Practice, OECD Environment Directorate and Centre for Tax Policy and Administration, OECD, Paris.

Steenblik, R. (2007), "Subsidies: The Distorted Economics of Biofuels", in OECD/ITF Roundtable, Biofuels: Linking Support to Performance, Paris.

Stern, N. (2009), A Blueprint for a Safer Planet, The Bodley Head, London.

Theaustralian.com, http://www.theaustralian.com.au/business/property/byron-bay-owners-can-hold-backsea/story-e6frg9gx-1225825706139.

Weitzman, M. (1974), "Prices vs. Quantities, Review of Economic Studies", 41 (4), pp. 477-491. 


\section{WORKING PAPERS}

The full series of Economics Department Working Papers can be consulted at www.oecd.org/eco/workingpapers/

886. Climate-Change Policy in the United Kingdom

(August 2011) by Alex Bowen and James Rydge

885. Improving Access and Quality in the Indian Education System

(August 2011) by Sam Hill and Thomas Chalaux

884. How Institutions Shape the Distributive Impact of Macroeconomic Shocks: A DSGE Analysis (July 2011) by Rudiger Ahrend, Charlotte Moeser and Tommaso Monacelli

883. Can India Achieve Double-Digit Growth?

(July 2011) by Richard Herd, Paul Conway, Sam Hill, Vincent Koen and Thomas Chalaux

882. Predicting peaks and troughs in real house prices

(July 2011) by Linda Rousová and Paul van den Noord

881. Public sector spending efficiency in Estonia: healthcare and local government

(July 2011) by Zuzana Smidova

880. How to move Product Market Regulation in New Zealand back towards the frontier (July 2011) by Paul Conway

879. Financial sector reform in India: time for a second wave?

(July 2011) by Richard Herd, Vincent Koen, Ila Paitnak and Ajay Shah

878. Policies to rebalance housing markets in New Zealand

(July 2011) by Calista Cheung

877. The sharing of macroeconomic risk: Who loses (and gains) from macroeconomic shocks (July 2011) Rudiger Ahrend, Jens Arnold and Charlotte Moeser

876. Estonia: making the most of globalisation

(June 2011) Robert Price and Andreas Wörgötter

875. The effects of downturns on labour force participation: evidence and causes

(June 2011) Romain Duval, Mehmet Eris and Davide Furceri

874 A dynamic factor model for world trade growth

(June 2011) Stéphanie Guichard and Elena Rusticelli

873. Towards a better understanding of the informal economy

(May 2011) Dan Andrews, Aida Caldera Sánchez and Åsa Johansson

872. Tax competition between sub-central governments

(May 2011) Hansjörg Blöchliger and José-Maria Pinero-Campos

871. The growth effects of current account reversals: the role of macroeconomic policies (May 2011) Luiz de Mello, Pier Carlo Padoan and Linda Rousová 
ECO/WKP(2011)56

870. Les politiques du logement en France

(May 2011) Bénédicte Rolland

869. How important is wealth for explaining household consumption over the recent crisis? An empirical study for the United States, Japan and the euro area

(May 2011) Clovis Kerdrain

868. Adjusting fiscal balances for asset price cycles

(May 2011) Robert Price and Thai-Thanh Dang

867. Improving the functioning of the housing market in the United Kingdom

(May 2011) Christophe André

866. An analysis of demand for foreign exchange reserves

(May 2011) Peter Vujanovic

865. Episodes of large capital inflows and the likelihood of banking and currency crises and sudden stops

(May 2011) Davide Furceri, Stephanie Guichard and Elena Rusticelli

864. The effect of episodes of large capital inflows on domestic credit

(May 2011) Davide Furceri, Stephanie Guichard and Elena Rusticelli

863. Medium-term determinants of international investment positions: the role of structural policies (May 2011) Davide Furceri, Stephanie Guichard and Elena Rusticelli

862. French social housing in an international context

(May 2011) Kathleen Scanlon and Christine Whitehead

861. Making the French housing market work better

(May 2011) by Hervé Boulhol

860. Surveillance by international institutions: lessons from the global financial and economic crisis (April 2011) by Kumiharu Shigehara and Paul Atkinson

859. France's environmental policies: internalising global and local externalities (April 2011) by Balázs Égert

858. Bringing French public debt down: the options for fiscal consolidation (April 2011) by Balázs Égert

857. Policy frameworks in the post-crisis environment (April 2011) by Nigel Pain and Oliver Röhn

856. Global imbalances, exchange rate pegs and capital flows: a closer look (April 2011) by Paul van den Noord

855 Interest rate pass-through during the global financial crisis: the case of Sweden (April 2011) by Niels-Jakob Harbo Hansen and Peter Welz 